\title{
Monpa, memory, and change: an ethnobotanical study of plant use in Mêdog County, South-east Tibet, China
}

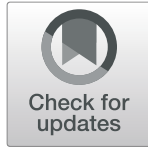

Shan $\mathrm{Li}^{1,2}$, Yu Zhang ${ }^{1}$, Yongjie Guo ${ }^{3,4}$, Lixin Yang ${ }^{1}$ and Yuhua Wang ${ }^{1 *}$

\begin{abstract}
Background: Due to their relative isolation, the previous studies of Monpa plant use were only conducted in north-east India. In October 2013, Mêdog County was no longer remote, thanks to completion of a highway into the county. This study of plant species used by the Monpa had three research objectives. These were (i) to identify and record local names and uses of plants in Mêdog County, (ii) to assess which of these were uses of endemic or near-endemic species within this part of the Indo-Burma biodiversity hotspot, and (iii) to assess how plant uses reflect socio-economic change in Mêdog County?

Methods: Field surveys were conducted in 12 villages of four townships in Mêdog County, Tibet, China. Two field visits were made. The first field trip was in November 2017 and the second field trip was in May 2018. We interviewed 64 key informants between 21 and 84 years old. Most of them were the village leaders and other local people who are knowledgeable about plants. After transect walks with knowledgeable local people, we used free listing, key informant interviews, and semi-structured interviews during the field work. Plants traditionally used by the Monpa were documented. Utilization frequency was used to assess the significance of each species, and the Cultural Importance index was used to estimate the cultural significance of the species in common. We also used the informant consensus factor (FIC) to determine the homogeneity of the informants' knowledge of medicinal plants.

(Continued on next page)
\end{abstract}

\footnotetext{
* Correspondence: wangyuhua@mail.kib.ac.cn

${ }^{1}$ Department of Economic Plants and Biotechnology, Key Laboratory of

Economic Plants and Biotechnology, Kunming Institute of Botany, Chinese

Academy of Sciences, Kunming 650201, China

Full list of author information is available at the end of the article
}

C The Author(s). 2020 Open Access This article is distributed under the terms of the Creative Commons Attribution 4.0 International License (http://creativecommons.org/licenses/by/4.0/), which permits unrestricted use, distribution, and reproduction in any medium, provided you give appropriate credit to the original author(s) and the source, provide a link to the Creative Commons license, and indicate if changes were made. The Creative Commons Public Domain Dedication waiver (http://creativecommons.org/publicdomain/zero/1.0/) applies to the data made available in this article, unless otherwise stated. 
(Continued from previous page)

Results: One hundred ninety-four plant species belonging to 82 families and 158 genera were recorded and collected. One hundred twenty-two species, primarily fruits, were food plants. Forty-five species were used as traditional medicines. This included highly valued species collected in alpine areas (Paris polyphylla) and brought to villages in Mêdog, which are at a lower altitude (between 728 and $1759 \mathrm{~m}$ a.s.l). Seven edible plant species were also used as herbal medicines. We also recorded 39 species used for other purposes in Monpa daily life. These included nine species that were used to make agricultural tools, five species for dyes and mordants, four species for timber, three species for fuelwood, four species for religious ritual use, three species for washing, two species for incense, two species for thatching, two species for fiber (rope and paper), two "calendar plants" were used to indicate seasons for agricultural purposes, two fish poison plant species, and one species were used as a tobacco substitute. Based on taxonomic insights and from studies elsewhere, we suggested that fiber species were under-reported (c. 14 species were used vs. one species reported used). Even though these plant species are rich and diverse, the use of endemic or near-endemic species was rarely recorded in previous studies. These species included Arenga micrantha (used for starch), Hornstedtia tibetica (fruits), Castanopsis clarkei (edible nuts) and Gnetum pendulum (edible nuts), Ophiorrhiza medogensis (vegetables), Derris scabricaulis (fish poison), Radermachera yunnanensis (agricultural tools), Litsea tibetana (seed oil), Dendrocalamus tibeticus (wine strainers and implements for administering medicine), Zanthoxylum motuoense (spices), Cinnamomum contractum (tobacco substitutes), Morus wittiorum (medicines), and Garcinia nujiangensis (funeral rituals). Despite the absence of roads until 2013 and the impression of "isolation," Monpa knowledge of plant use reflects three categories of change. Firstly, oral histories of plants used in Bhutan were also encountered by Monpa people after their migration from Bhutan to south-eastern Tibet. Secondly, a "slow change" through centuries of exchange of knowledge (for example of Chinese and Tibetan medical systems), seeds of introduced crops (finger millet (indigenous to Africa), maize (from Meso-America)), and experimentation and use of introduced medicinal plants (such as Datura stramonium, which originates from North America). Thirdly, "fast change" over the past decade. This is reflected in changes in traditional architecture and in rising commercial trade in selected plant resources such as Dendrobium orchid stems and Paris polyphylla rhizomes which are in demand in China's Traditional Chinese Medicine (TCM) markets).

Conclusions: Monpa people in the south-eastern Tibet have detailed knowledge of the diverse plant resources. But that traditional knowledge is now faced with a crisis because of the modern socio-economic change. In addition, Monpa knowledge of plants reflects slower changes in knowledge as well. For example, Monpa ethnomedicine has been influenced by traditional Tibetan and Chinese medicine over a longer period in time. Overall, this study provides a deeper understanding of the Monpa peoples' knowledge on wild plants, including endemic and near-endemic species whose uses have not been previously recorded. Several of these narrowly distributed species, such as the fish poison Derris scabricaulis, could be the focus of further studies. Some wild edible plants may also have interesting dietary constituents which need in-depth studies. These detailed studies could enable the Monpa people to benefit from the use of their traditional plantderived culture and therefore support the biodiversity conservation.

Keywords: Indo-Burma biodiversity hotspot, endemic plants, Monpa, cultural change

\section{Background}

\section{Introduction}

This study was carried out in Mêdog County in the south-eastern Tibet, at the edge of two "biodiversity hotspots" which were the Himalayan and the Indo-Burma biodiversity hotspots. Due to its biogeography, topography, and altitudinal range (a difference of $7500 \mathrm{~m}$ over $40 \mathrm{~km}$ ), south-east area of Tibet has high levels of biodiversity. South-eastern Tibet is also culturally diverse, with Tibetan, Hui, Monpa, Lhoba people developing cultural landscapes through farming, pastoralism, wild plant use, and management. The need to combine traditional ecological knowledge with management strategies to achieve biodiversity conservation in local beliefs and practices is well recognised [1]. In their review of conservation needs for the Indo-Burma biodiversity hotspot, for example, the CEPF (2012) stressed the need for "greatly improved information on status and distribution in Indo-Burma to highlight species for which available information is so limited that it precludes any form of meaningful conservation action". This study is a contribution toward both conservation and development.

Although a few studies have been done on Monpa plant use in north-east India [2], this is the first study of Monpa ethnobotany in this formerly remote part of China. No longer remote, this area is undergoing rapid socio-economic change, which may lead to declining knowledge of local plant uses. In other parts of the 
region, however, 68 medicinal plant species were recorded as used by Tibetans in Shangri-la, Yunnan, China [3]. Traditional knowledge of 168 wild edible plant species were recorded in Tibetans of Shangri-la region, Yunnan, China [4]. The uses of 81 species of vascular plants were recorded in Tibetans of Zhouqu county, Gansu, China [5]. The uses of 54 species of vascular plants and 22 mushrooms were recorded in Tibetan community of Zhagana in Tewo County, Gansu, China [6].

\section{Study aims and research objectives}

The aim of this study was to document the ethnobotanical knowledge of the Monpa people in Mêdog County, south-eastern Tibet. As no previous studies had been done on Monpa plant use in China, we had three research objectives. These were (i) to identify and record local names and uses of plants in Mêdog County, (ii) to assess which of these were uses of endemic or nearendemic species within this part of the Indo-Burma biodiversity hotspot, and (iii) to assess how current plant uses reflect socio-economic change in Mêdog County?

\section{Methods}

\section{Location of the study sites}

Mêdog County is the most remote county in the southeastern Tibet, which covers a total area of approximately $31,395 \mathrm{~km}^{2}$, located in the lower river valley of the Yarlung Tsangpo River. It is called "Pe-ma-ko" by the Tibetan Buddhists, meaning "hidden lotus." The average annual temperature in Mêdog County ranges from 16 to $18{ }^{\circ} \mathrm{C}$. The lowest temperature is $2{ }^{\circ} \mathrm{C}$ in January and the highest temperature is $33.8{ }^{\circ} \mathrm{C}$ in July. The annual average rainfall is $2350 \mathrm{~mm}$, the frost-free period is about 330 days, and the average humidity is over $80 \%$. In the horizontal distance of $40 \mathrm{~km}$, Mêdog County has an altitudinal difference of more than $7500 \mathrm{~m}$, with plant species ranging from alpine plant species to tropical plant species and complex vegetation structures $[7,8]$.

We had selected 12 villages belonging to four townships in the Mêdog County from different altitudes for investigation (Table 1). Monpa people accounted for 99.2\% of the total population of the Beibeng Township. Dexing Township is the nearest township to the Mêdog County. It is located on the right bank of the Yarlung Tsangpo River, across the river from Mêdog County. Bangxin Township is situated in the northeast of Mêdog
County and "Bangxin" which means "flat land" in Tibetan language. Jiaresa Township is located in the northern part of Mêdog County and is one of the three remote towns in the Mêdog County (Table 1).

The location of the 12 study villages in Mêdog County are shown in Fig. 1. The names and altitudes of the seven villages of Beibeng Township are Beibeng Village (839 $\mathrm{m}$ a.s.l), Jiangxin Village (893 $\mathrm{m}$ a.s.l), Xirang Village (823 m a.s.l), Gelin Village (1759 m a.s.l), De'ergong Village (1552 $\mathrm{m}$ a.s.l), Badeng Village (1316 $\mathrm{m}$ a.s.l), and Acang Village (1342 $\mathrm{m}$ a.s.l). The altitudes of the three villages in Dexing Township are Dexing Village $(728 \mathrm{~m}$ a.s.l), Hezha Village (1051 m a.s.l), and Naerdong Village (1571 $\mathrm{m}$ a.s.l). We also studied one village in Bangxin Township: Bangxin Village (1162 $\mathrm{m}$ a.s.l) and one village in Jiaresa Township: Gengbang Village (1330 m a.s.l).

\section{Cultural background: Monpa in Mêdog}

The literal meaning of Monpa is "man of the lower country," referring to several ethnically related peoples, which may not be related linguistically [9]. In the early to mid-eighteenth century, due to the hardships and heavy taxes in Bhutan at the time, the local Monpa people heard that there was a sacred place in the southeast of Tibet, called Pe-ma-ko (now Mêdog), where there was the chance for a better life, so they decided to flee from Bhutan to Tibet [10]. The oldest record of mentioning Monpa was the Tibetan epic of King Ling Gesar during the fourth century [11]. The language used by "Monpa" belongs to the Tibeto-Burman language group of the Sino-Tibetan language family [9]. However, the Monpa people do not have their own written characters. Consequently, the history of the Monpa people is known through oral histories and Tibetan literature [12]. In 1964, the Monpa group was officially recognized as an independent ethnic group by the People's Republic of China [13] and approximately 25,000 Monpa currently reside in the low-altitude areas of Tsona, Nyingchi, and Mêdog in the Tibet Autonomous Region of China [14]. In China, the highest population of Monpa speakers lives in Mêdog County, a biologically and culturally diverse region that is $34,000 \mathrm{~km}^{2}$ in extent.

\section{Field survey}

Ethnobotanical fieldwork took place over 45 days spreading between November 2017 and May 2018. We

Table 1 Basical geographical information of the Townships

\begin{tabular}{|c|c|c|c|c|}
\hline Township & Beibeng & Dexing & Bangxin & Jiaresa \\
\hline Elevation & $400-3260 \mathrm{~m}$ & $850 \mathrm{~m}$ & $1240 \mathrm{~m}$ & $1120 \mathrm{~m}$ \\
\hline Climate & $\begin{array}{l}\text { Low mountain tropical humid climate and } \\
\text { Mountain subtropical semi-humid climate }\end{array}$ & $\begin{array}{l}\text { Low mountain tropical humid climate and } \\
\text { Mountain subtropical semi-humid climate }\end{array}$ & $\begin{array}{l}\text { Mountain subtropical } \\
\text { semi-humid climate }\end{array}$ & $\begin{array}{l}\text { Mountain subtropical } \\
\text { semi-humid climate }\end{array}$ \\
\hline Population & 2371 & 1668 & 1370 & 581 \\
\hline
\end{tabular}




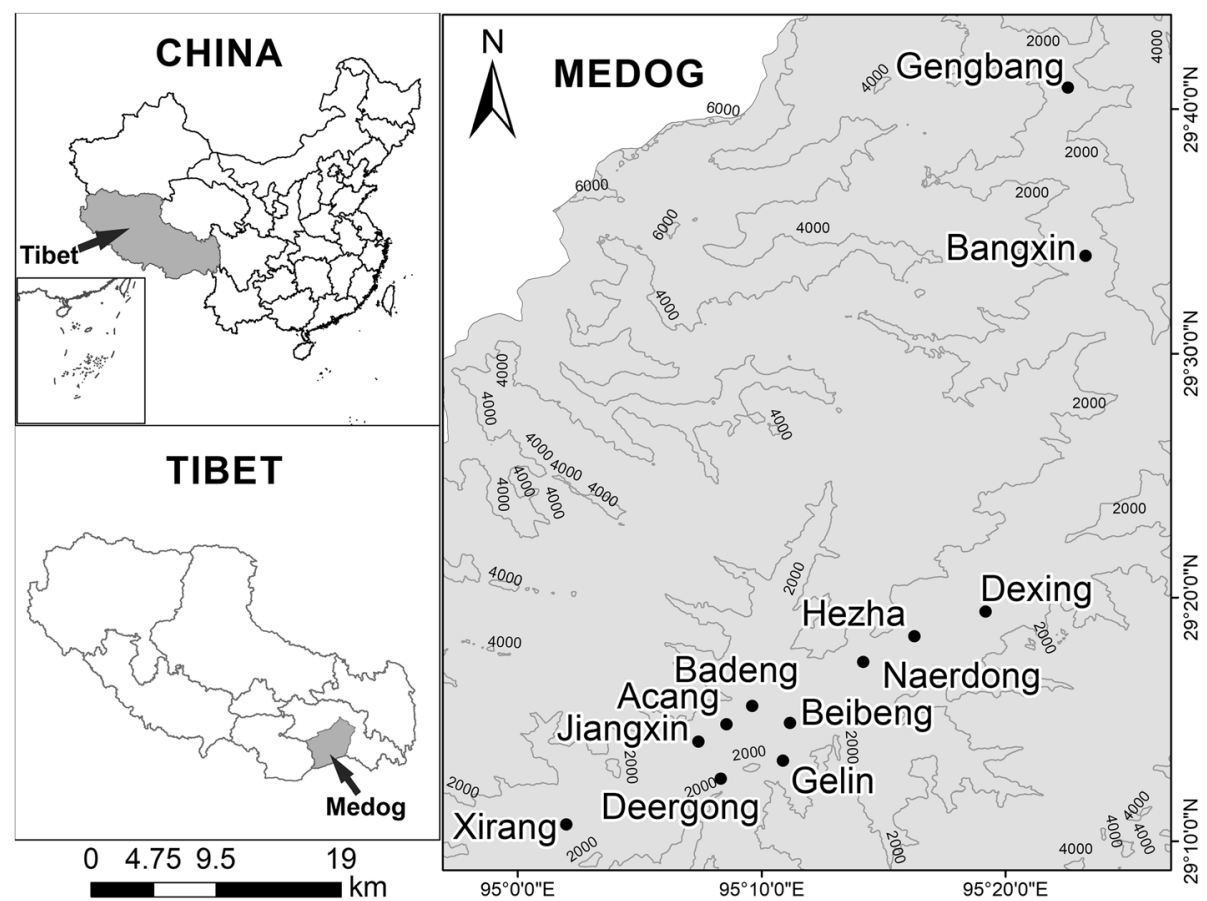

Fig. 1 The location of Villages in in Mêdog County, Tibet, China

interviewed 64 key informants. After transect walks with knowledgeable local people, information was collected through free listing, semi-structured, and key informant interviews, participatory approaches and group discussions. Most of key informants were the village leaders and the knowledgeable persons in the village. The age of key informants ranged between 21 and 84 years old. The interviews included the questions that were relevant to document detail information on all useful wild plants. The questions investigated included: What is your age? What is the local name of each plant? What are the most frequently used parts? What ailment does this plant treated? What is the cooking or preparation method of each plant? Do you know any other uses of the plants? We documented the ethnobotanical information for each plant, including scientific name, vernacular name, parts used, habitat and other specific purposes. Additional file 1 and Additional file 2 local writing system is derived from Tibetan language, so the local name is spelled by the writing system which is founded by Turrell Wylie (https://www. omniglot.com/writing/tibetan.htm) (Additional files 1 and 2). Scientific names of plants were confirmed by The Plant List (http://www.theplantlist.org). All the voucher specimens of listed species were collected and deposited at the herbarium of Kunming Institute of Botany.

\section{Data analysis}

Ethnobotanical quantitative indices including utilization frequency, informant consensus factor (FIC), and cultural importance index $(\mathrm{CI})$ were adopted. The use frequency of certain species was estimated by utilization frequency:

$$
f=\frac{N_{m}}{N_{i}}
$$

Where $N_{m}$ was the number of certain species mentioned by informant, and $N_{i}$ was the total number of informants. High $f$ values indicated the plant used frequently [15].

FIC was determined using the following formula to evaluate the information of medicinal plants distributed between informants and to determine the homogeneity of informant's knowledge on medicinal plants.

$$
\mathrm{FIC}=\frac{N_{u r}-N_{t}}{N_{u r}-1}
$$

Where $N_{u r}$ was the number of use reports from informants for each ailment category, and $N_{t}$ was the total number of species used by all informants for this ailment category. Values of FIC ranging between 0 and 1. High FIC values (close to one) showed the agreement among the informants about this ailment category. On the contrary, low FIC values (close to zero) showed disagreement among the informants [16].

Each species mentioned by an informant within one use category was a use report (UR). Cultural importance index (CI) was used to indicate the spread of the use 
(number of informants) of each species as well as to determine diversity of uses.

$$
\mathrm{CI}_{\mathrm{s}}=\sum_{u=u_{1}}^{u_{N C}} \sum_{i=i_{1}}^{i_{N}} \frac{U R_{u i}}{N}
$$

$N$ was the total number of informants and $\mathrm{NC}$ was the total number of use categories. CI was the sum of the proportion of informants that mentioned each of the use categories for a given species. The higher CI value indicated the multiple uses of a species [17].

\section{Results and discussion}

\section{Diversity and enumeration of Monpa plant use}

This study has documented 194 plant species belonging to 82 families and 158 genera used by Monpa people in Mêdog County (Table 4 in Appendix). Of these plant species, 84 were herbaceous $(43.3 \%), 52$ species were trees (26.8\%), 35 species were shrubs (18\%), and 23 species were lianas or vines (11.9\%). The survey results reveal that there are 45 species of ethnomedicinal plants, 122 species of local edible plants, and 39 plant species has been traditionally consumed as other purposes in Monpa daily life, including agriculture tools (9), dyes (5), incense (2), timber (4), fuelwood (3), religious ritual use (4), washing (clothes and hair) (3), thatching (2), fish poisons (2), fiber (2), seasonal indication (2), and a tobacco substitute (1) (Fig. 2).

In contrast to the staple diet of naked barley, yak meat, mutton, buttered tea, and barley wine of traditional Tibetan, they seldom eat vegetables or fruits, yet plant resources in Mêdog County are more plentiful. Monpa people have a wide variety of vegetables and beverages in their traditional daily diet. The most frequently used part is the fruit (58 species, 47.5\%) in this study, which is consistent with the situation in northeast India, which has similar bio-climatic conditions [18]. This demonstrates the rich diversity of wild fruits and vegetables in the region, providing local residents with sustainable economic pillars and livelihood security by targeting wild edible fruits and vegetables that can be developed commercially [18]. Out of 122 wild edible species, seven are also used as herbal medicine. Equisetum ramosissimum, for example, the root of this species is usually eaten directly as a fruit and boiling the aerial part could be used for treating rheumatism. Wild edible plants with high $\mathrm{CI}$ values may have peculiar dietary constituent and require further research. In addition, the alcoholic beverage consumed by almost all Nepalese and Tibetans (known as "jnard") which has the same ingredients as this yellow "wine" in Mêdog County [19]. Seasonal fishing and fishing by poison are also great economic activities for many tribal people in the world. Studies in Nepal recorded that four entirely different plant species exploited as fish poison plants [20]. Tsering et al.'s study was focused on higher altitude species used by Monpa people, including the medicinal plants Aconitum heterophyllum, Neopicrorhiza scrophulariiflora, Paris polyphylla, Rhododendron hodgsonii, Swertia chirayita, and Taxus baccata [2]. In our study, one of these higher altitude species was recorded (Paris polyphylla).

\section{Edible fruits and vegetables}

Food categories include fruit, vegetable, starch, oil, nut, beverage, condiment, and forage (Fig. 3). The most widely used wild edible species are fruits $(42$

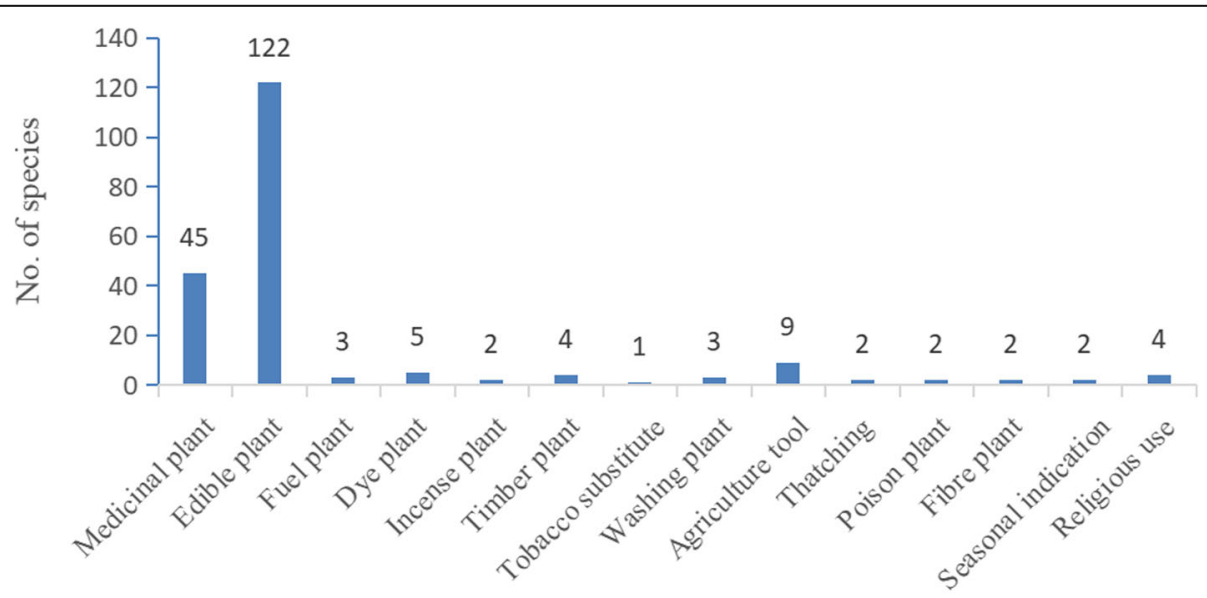

Different categories of local use

Fig. 2 Plants used for different purposes by the Monpa ethnic group in Mêdog County, Tibet, China 


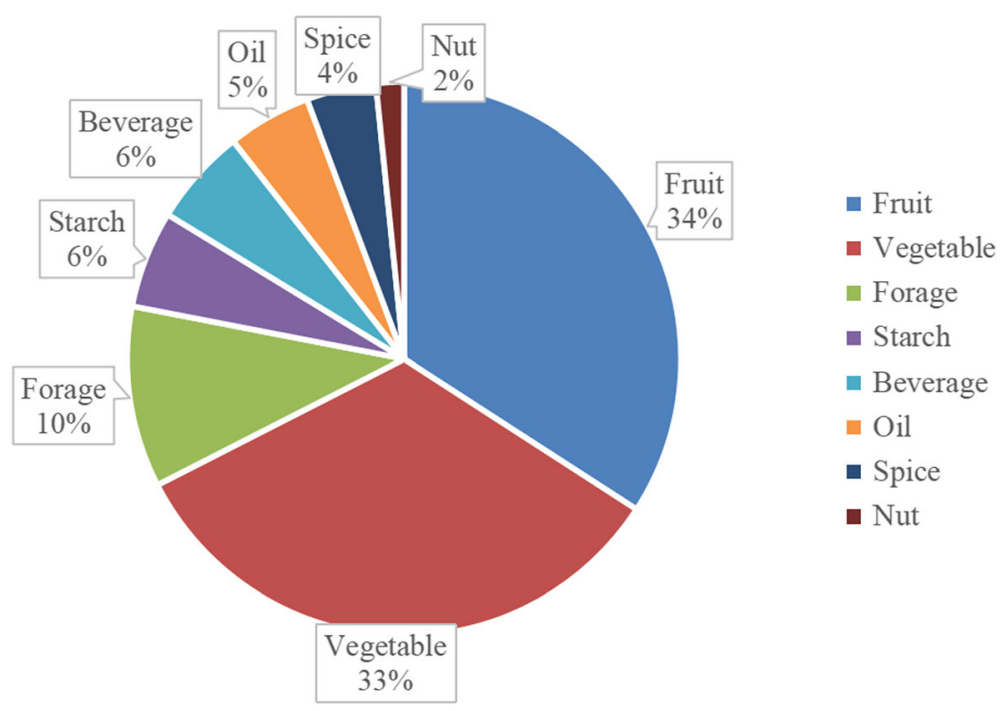

Fig. 3 Different categories of edible plants used by the Monpa ethnic group in Mêdog County

species), followed by vegetables (41 species). The Monpa depended on wild fruits with high CI values such as Saurauia punduana (0.78), Elaeocarpus braceanus (0.5), Duchesnea indica (0.41), or Ficus semicordata (0.39) for vitamins and nutrients. The same as Lhoba people [21], Monpa depended on fruits from wild edible species which may be related to the low productivity of cultivated fruit trees of the Monpa group. Rubus ellipticus Sm. (0.33) is a renowned wild edible fruit to Monpa ethnic people in Mêdog County, whose ripe fruits can be taken orally and act as medicine for aperient and juice of the tender leaves cures oral ulcers in the district Udhampur, $J \& K$, India [22]. Monpa people have been using stone casseroles as cookware since ancient times [23]. Monpa people like to eat "hot-pot" dishes in the stone casserole including wild vegetables and meat which are a popular food combination in Mêdog County. Wild vegetables with high CI values included Crassocephalum crepidioides (0.78), Pimpinella diversifolia (0.56), Rorippa dubia (0.31), Solanum torvum $(0.2)$, and Gonostegia hirta (0.08). Gonostegia hirta is a leafy vegetable that is also used as a functional food to provide energy for children and elders [24]. It is interesting that while it is used as a medicine in Bhutan [25], Entada rheedii is a popular addition to food by Monpa people. The cooking method for Entada rheedii is time-consuming due to the toxicity of the seeds. The seeds have to be detoxified by leaching and heating. The seeds are boiled with water, which is poured off each time to clear away the toxicity, then refilling the pot with water, repeating the process more than ten times. The Entada rheedii seeds are then cut into pieces and fried with rice.

Other categories were less frequent in use such as forage (13), starch (seven), beverage (seven), oil (six), spice source plant (five), and nuts (two). However, Monpa people have a rich tradition of extracting beverage, starch, and oil from specific plants in the region.

\section{Fermented beverages}

Traditional consumption of alcoholic beverages is an ancient tradition that is still an integral part of Monpa society. The Monpa people have the traditional custom of "three bowls of wine", meaning that guests have to drink three bowls of yellow wine before they enter the door to show their friendship. Seven plant species were used to produce a yellow "wine." The mainly ingredients were rice (Oryza sativa L.), maize (Zea mays L.), Eleusine coracana, and Fagopyrum esculentum. Buddleja asiatica is the most important plant species during the preparation of alcoholic beverage fermentation by Monpa people in Mêdog County. Based on the uses of Buddleja lindleyana and Buddleja officinalis in coloring rice yellow [26] and B. officinalis in indigo fermentation [27], we suggest that $B$. asiatica is a dual purposeful species, as both a wine colorant and a source of microorganisms that an aid to fermentation (Fig. 4).

\section{Starch sources}

Starch in Monpa people diets was supplemented by starch processed from wild species. Cultivated starch 


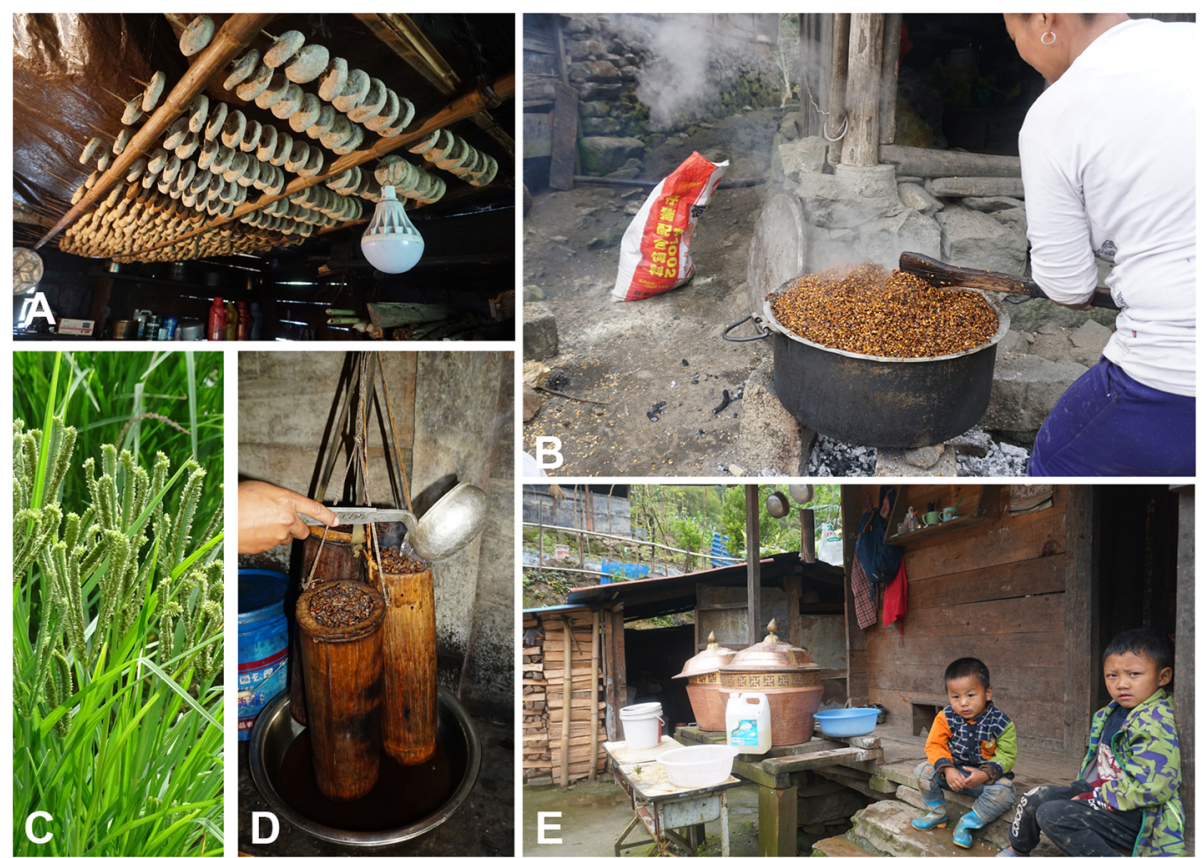

Fig. 4 The "yellow-wine" production process. a "Cakes" used to start rice "wine" fermentation drying on a bamboo rack. These are made from a mix of species based on a secret recipe. b Preparing the starch base for "yellow wine" from rice (Oryza sativa), maize (Zea mays), Eleusine coracana, and Fagopyrum esculentum. c Finger millet (Eleusine coracana). d Straining the wine using a strainer made from Dendrocalamus tibeticus culms. e Ready for a welcome drink of three cups of yellow wine: cultural and social values underpin the continued production of the yellow wine

sources were from both cereal crops and cultivated tubers (Table 4 in Appendix). The cultivated cereals were buckwheat (Fagopyrum esculentum and Fagopyrum tataricum), finger millet (Eleusine coracana) rice, and maize. Three taro (Colocasia) species and four yam (Dioscorea) species were cultivated as starch sources (Table 4 in Appendix). Of these, Dioscorea alata tubers have $80 \%$ starch in dry matter [28] and Colocasia esculenta have $70-80 \%$ starch in dry matter [29]. Wild species also provided supplementary starch sources (excluding the starch-rich seeds of Entada rheedii mentioned in the previous section). Two of these were palms (Table 4 in Appendix) in the genus Arenga. As Ellen points out [30], this is one of main starchproducing palm genera used for food in Asia, the other genera being Borassus, Caryota, Corypha, Eugeissona, and Metroxylon. Starch production from Arenga micrantha is poorly known as it is endemic to Mêdog County [8] and is documented in this study (Fig. 5). In contrast, Arenga pinnata is widely distributed in Asia, where it is most commonly served as palm sugar [31], but is also used as a starch source [30]. Other starch sources were Alsophila articulata and Chenopodium album. Today, the uses of Arenga micrantha, Arenga pinnata, and Alsophila articulata are almost abandoned. This decrease in consumption of these wild starch sources has increased the production of cultivated cereal crops in Mêdog County [32].

\section{Seed oils}

The Monpa in Mêdog County totally used six wild edibles as the source of oil and fats. One of these species, Perilla frutescens, was also widely used in various tribal groups of the northeast India [33]. Moreover, Perilla frutescens oil is rich in natural compounds that could be developed as nutraceuticals and/or phytomedicine [34].

\section{Medicinal plant use}

According to our survey results, 45 plant species are used as herbal medicines for treating 13 different categories of human ailments. Botanical and ethnobotanical information about these plant species include scientific name, family name, vernacular name, part(s) used, the method of preparation, the ailments treated, and voucher specimen number. Just over half medicinal plants were herbs (51.1\%). This agrees with reports from the lower elevation of Bhutan that most of the ethnobotanical plants were herbs [25]. The common use of herbs as sources of medicine found in this study were also indicated by studies conducted elsewhere 

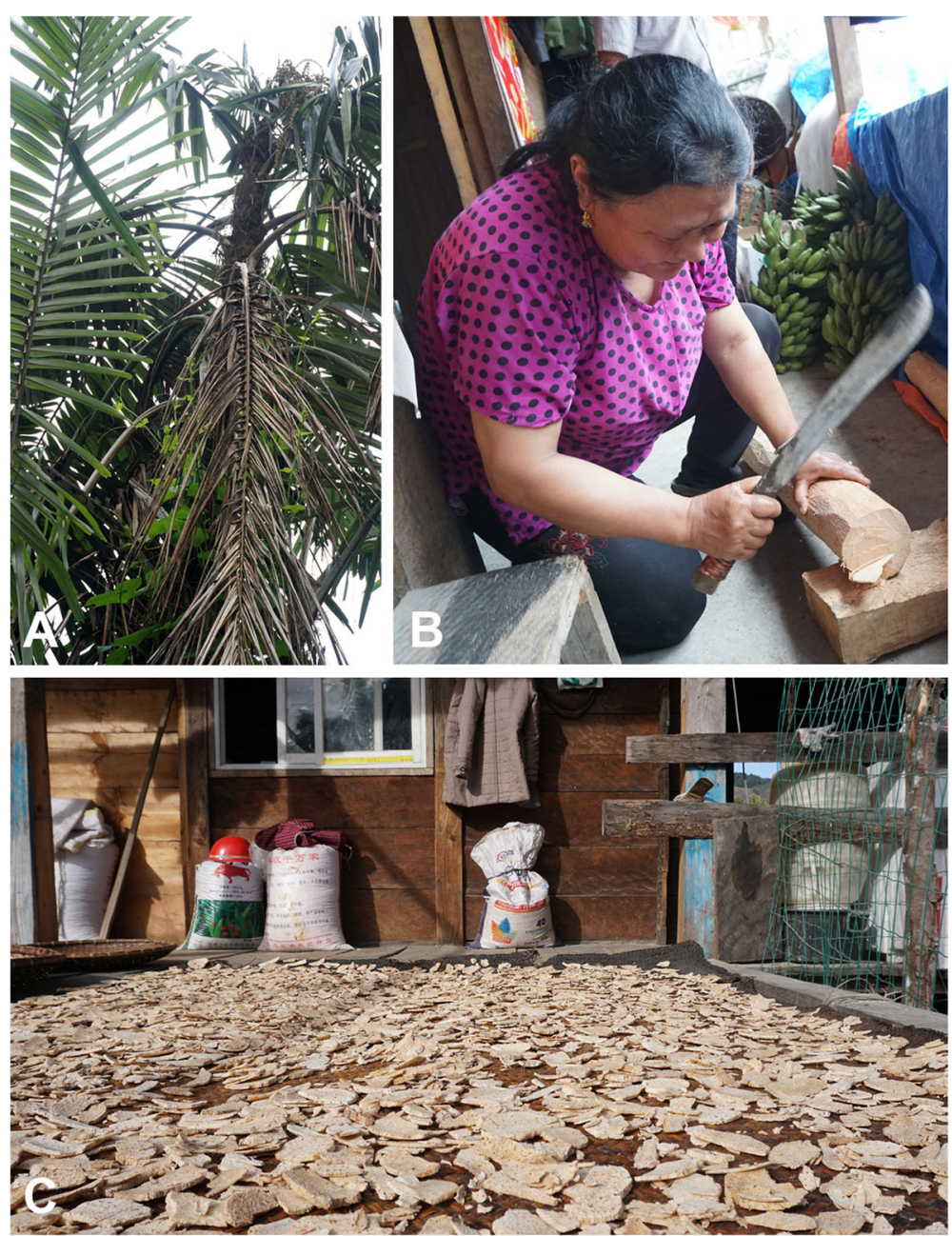

Fig. 5 Arenga micrantha, a near endemic starch source. a A. micrantha showing leaves and stems. b Slicing the starch rich pith. c Slices of $A$. micrantha drying before storage

$[35,36]$. Leaves $(40 \%)$ are the most predominantly used parts of these medicinal plants, followed by roots $(22.2 \%)$, fruits $(15.6 \%)$, seeds (11.1\%), stems (6.7\%), whole plant (6.7\%), branches $(6.7 \%)$, and burgeons (4.4\%). The preference for leaf has also been recorded among the traditional Tibetan doctors of Mustang district of the north-central part of Nepal [35].

Uses for all illnesses for wild medicinal plants are locally classified into 13 categories (Table 2). These are skin and subcutaneous tissue diseases, circulatory system, immune system, genitourinary ailments, neurological diseases, inflammation, gastrointestinal ailments, endocrine and metabolism disorders, respiratory system disorders, leech bites, snake bites, abortion, musculoskeletal system disorders, and other diseases. FIC results for the 13 illness categories ranged from 0 to 0.75 , with the highest for musculoskeletal system disorders $(\mathrm{FIC}=0.75$; two species, five use-reports), immune system diseases ( $\mathrm{FIC}=0.67$; two species, four use-reports $)$, and respiratory system disorders ( $\mathrm{FIC}=0.6$; three species, six usereports) (Table 2). One of the important livelihoods of the Monpa is hunting; the highest FIC for musculoskeletal system disorders is related to the damage caused by the accidents.

An empirical observation on the use of medicinal plants by the Monpa people of Mêdog County study area requires cross-validation with published literature on phytochemical and pharmacological properties of medicinal plants reported in this study to verify their effectiveness. Our literature review of 21 medicinal plant species shows that local uses are generally consistent with known pharmacological properties. And based on a literature review, 11 medicinal plant species had partial uses similar with reported pharmacological properties. 
Table 2 Informant consensus factor for traditional medicinal plant use categories

\begin{tabular}{|c|c|c|c|}
\hline Illness category & Number of taxa $\left(N_{t}\right)$ & $\begin{array}{l}\text { Number of } \\
\left.\text { use-reports ( } N_{\text {ur }}\right)\end{array}$ & $\begin{array}{l}\text { Informant consensus } \\
\text { factor (FIC) }\end{array}$ \\
\hline Circulatory system such as high blood pressure, altitude sickness & 3 & 4 & 0.33 \\
\hline Endocrine and metabolism disorders such as diabetes & 1 & 1 & - \\
\hline $\begin{array}{l}\text { Gastrointestinal ailments such as diarrhea, stomach pain, cholecystitis, } \\
\text { intestinal worms }\end{array}$ & 6 & 10 & 0.44 \\
\hline Genitourinary ailments such as menstrual problems & 2 & 2 & 0 \\
\hline Immune systerm such as rheumatism & 2 & 4 & 0.67 \\
\hline $\begin{array}{l}\text { Inflammation, suppuration, infective, toothache, sinusitis, clear heat and } \\
\text { detoxification }\end{array}$ & 8 & 17 & 0.56 \\
\hline Malaria, mosquito and flea repellent, snake bite, leech bite & 5 & 8 & 0.43 \\
\hline Morning sickness, abortion & 2 & 3 & 0.5 \\
\hline Musculoskeletal system such as sprain, arthritis & 2 & 5 & 0.75 \\
\hline Neurology diseases such as epilepsy, acute alcoholic intoxication & 4 & 6 & 0.4 \\
\hline Others (heat stroke, refreshing, killing insects, rice blast) & 4 & 5 & 0.25 \\
\hline Respiratory system disorders such as cold, sore throat and stuffy nose & 3 & 6 & 0.6 \\
\hline $\begin{array}{l}\text { Skin and subcutaneous tissue diseases such as wound, bruises, psoriasis, } \\
\text { allergy, scar, leprosy, bleeding, bad skin odor }\end{array}$ & 16 & 28 & 0.44 \\
\hline
\end{tabular}

To date, no research studies are available on the phytochemical constituents or pharmacological properties of the Cinnamomum contractum, Brassaiopsis hainla, Fraxinus floribunda, or Zanthoxylum motuoense.

Literature studies indicated that seven species, namely Artemisia vestita, Coix lacryma-jobi, Equisetum ramosissimum, Oxalis corniculata, Persicaria capitata, Uncaria rhynchophylla, and Uncaria scandens, were used in Tibetan medicine to treat the same ailments [37]. Four other species (Curcuma aromatica, Dendrobium catenatum, Elaeocarpus braceanus, Sambucus williamsii) were possibly the substitutes for Curcuma longa L., Dendrobium nobile Lindl, Terminalia chebula Retz., and Sambucus adnata Wall. in Tibetan medicine. And only one species (Paris polyphylla) was used for different purpose by the Monpa than in Tibetan medicine.

Comparison of the information on traditional medicinal plant use of Monpa ethnic group with ethnobotanical studies conducted in the lower elevation of Bhutan, which has similar bio-climatic conditions [25], shows that only one wild medicinal plant, Datura stramonium, is used in the same for toothache (Table 3).

\section{Natural dyes and mordants}

Strobilanthes cusia (Yang-shar-pa), Rubia wallichiana (Lae-nyi), Rubia membranacea (Lae-nyi), Eurya acuminata (Zem-shing), and Curcuma longa (Dgrong) are the commonly used species in traditional dye processes. Fresh stems and leaves of Strobilanthes cusia are a well- known indigo source [78]. Boiling the stems of Rubia membranacea are used as a red dye. Mashed Curcuma longa tubers are used to dye threads yellow, while Eurya acuminata is used to dye threads green. In India, Eurya acuminata is used as a mordant together with Rubia cordifolia [79]. Whether E. acuminata is used in Mêdog as a mordant with Rubia membranacea or Rubia wallichiana is unknown at this stage, but is worth further investigation. This is because the genus Eurya (Pentaphylacaceae) is a known aluminium hyperaccumulator group [80] that are effective as mordants for red dye processes together with anthroquinone rich dye species, including Rubia [81].

\section{Paper making}

The Monpa community in Linzhi city is famous for hand-made paper for religious scripts that is made from the stem bark of Edgeworthia gardneri. Peeling the stem bark and removing the outermost layer of the stem bark, the remaining parts are soaked in the water, then stir the solution into a viscous state, pour the solution into a wooden flat mold, and dry it into a paper. Linzhi paper is better than Tibetan paper produced elsewhere.

\section{Fibers for rope and string}

Although Edgeworthia gardneri (Thymelaceae) can also be used for making rope and string, the value of this species for paper making may be a reason why this alternative use was not mentioned by local people 


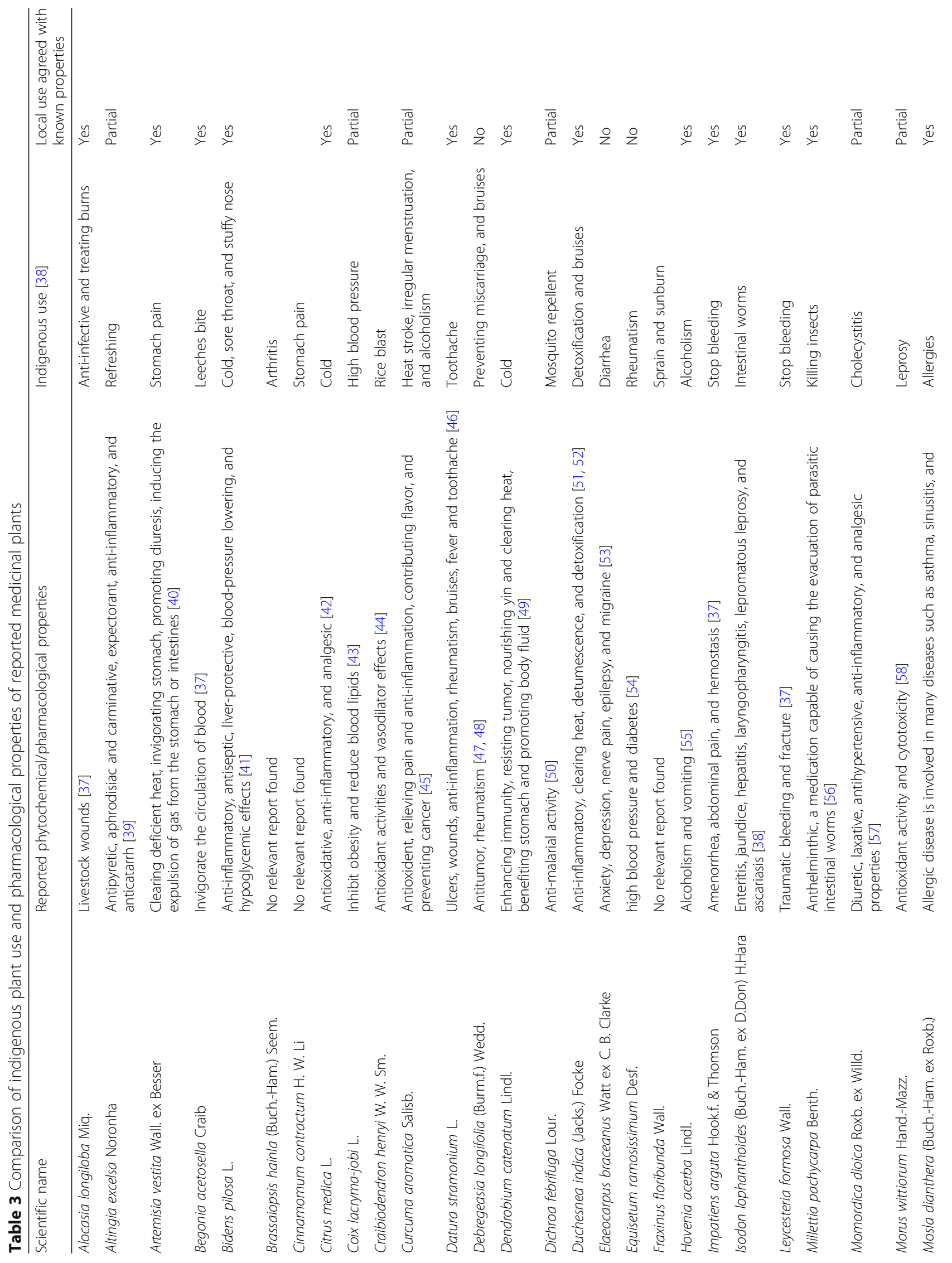




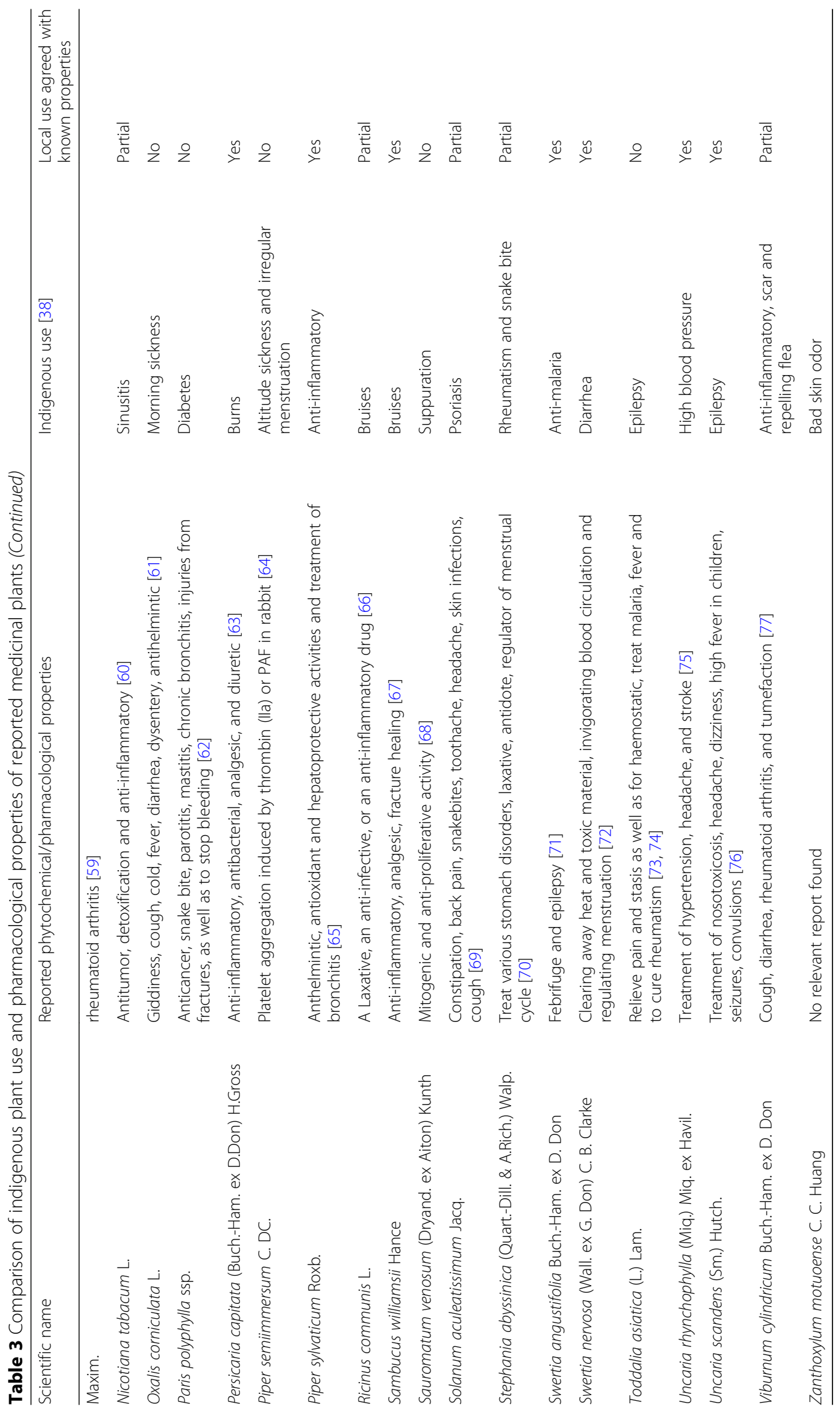


during our fieldwork. What was mentioned as a source of rope was the aerial roots of Poikilospermum lanceolatum (Urticaceae). Based on taxonomic insights and from studies elsewhere, however, we suggested that fiber species were under-reported (c. 14 species in four families (Fabaceae, Moraceae, Urticaceae, and Thymeleaceae) were used compared to the use of just one species (Poikilospermum lanceolatum) reported used for rope making). For example, Debregeasia longifolia (Urticaceae) is known for the quality of its fibers from other parts of China and Millettia pachycarpa (Leguminosae) bark is also recorded used for rope in the Flora of China (www.efloras.org). It is also likely that the bark of Moraceae (Ficus auriculata, Ficus cyrtophylla, Ficus oligodon, Ficus semicordata, Ficus subincisa, Morus alba, and Morus wittiorum) are also used for rope or twine. As is the stem bark of several Urticaceae (Elatostema cuneiforme, Elatostema nasutum, Gonostegia hirta, Pilea hilliana).

\section{House construction, tools, and utensils}

Morus wittiorum, Celastrus glaucophyllus, Terminalia myriocarpa, and Pinus wallichiana are the main timber species that the Monpa used for building their houses, of which Terminalia myriocarpa is the best quality of all timber species but cannot be chopped now because of it is vulnerable species according to the China Red Data Book [82]. Erythrina arborescens, Wendlandia tinctoria, Maesa rugosa, Radermachera yunnanensis, Abroma augusta, Macaranga denticulata, and Phrynium placentarium are used to make agricultural tools or daily-life utensils. For example, Wendlandia tinctoria can be used to make hilts for knives and Erythrina arborescens is used to make carvings for religious rituals.

Imperata cylindrica and Themeda villosa are used for thatching, of which the quality of Imperata cylindrica is better than Themeda villosa. Themeda villosa are covered on the roof, paved $5 \mathrm{~cm}$ thick, and changed once in 3years, but Imperata cylindrica can be maintained 7 years.

In addition to use of bamboo (mainly Bambusa teres and Dendrocalamus tibeticus) for making household utensils, the rattan Calamus acanthospathus is used to make baskets (Fig. 6). This widespread species is found in China (Tibet, Yunnan) as well as in Bhutan, India, Laos, Myanmar, Nepal, Thailand, and Vietnam which is also used as a source of edible greens (from the young shoots).

\section{Ritual uses of plants}

The Monpa belief systems, derived from the preBuddhist Bon religion and from Tibetan Buddhism, also link to animistic beliefs, where even the new houses have soul [83]. Laurocerasus undulata seeds oil and liquor are blended together during religious rituals by Monpa people, and then poured near the house to drive away misfortune and malevolent spirits. Nowadays, Monpa culture has been deeply influenced by Tibetan culture and most of the Monpa people believe in Tibetan Buddhism. Cinnamomum iners and Elsholtzia blanda are used as incense sources, which play an important role in the religious rituals of the Monpa. Luculia gratissima locally called "nom-meng" is also used as an offering in religious rituals.

The Monpa in Mêdog County have a unique funeral culture owing to the special geographical environment, cultural background, and religious beliefs. The practice of re-burial occurs when after burial, the bones are dug out for cremation, and the ashes are scattered into the Yarlung Tsangpo River. This cremation is ignited by the leaves of Altingia excelsa locally called "Sang-shing," which was used by the Monpa people to burn the body. In the meantime, yak butter and liquor are periodically added to the fire, along with offerings of rice, maize, and "Konpu" (Eleusine coracana). Secondly, put the leaves and stems of "Sra-gu" (Arundo donax) and the branches of "La-ga-dong-shing" (Garcinia nujiangensis) in turn. The leaves of "Sang-shing" are an essential ignition material for every funeral of the Monpa people.

\section{Fish poisons}

Seasonal fishing and hunting are great economic activities of Monpa ethnic community in addition to agriculture. Fishing by poison was well-known throughout the world in historical time [84]. Derris scabricaulis and Hydrocotyle javanica are poisonous plants used by the Monpa people in Mêdog County for fishing. A proper amount of poisonous plants are soaked in the water, the fish will lose consciousness and float to the water within half an hour. However, if you could not catch the fish in time, the fish will wake up. No relevant reports about these two poisonous plants were found. However, the rotenones, saponins, and cyanide are the main active ingredients of these fish poison species [85].

\section{Calendar plants}

According to our investigation, Mussaenda pubescens and Meliosma pinnata are used for indicating the time of sowing maize by Monpa people. Mussaenda pubescens blossoms and the weather is fine, then you can sow the seeds in the field, but you cannot sow the seeds after the blooming period of Meliosma 

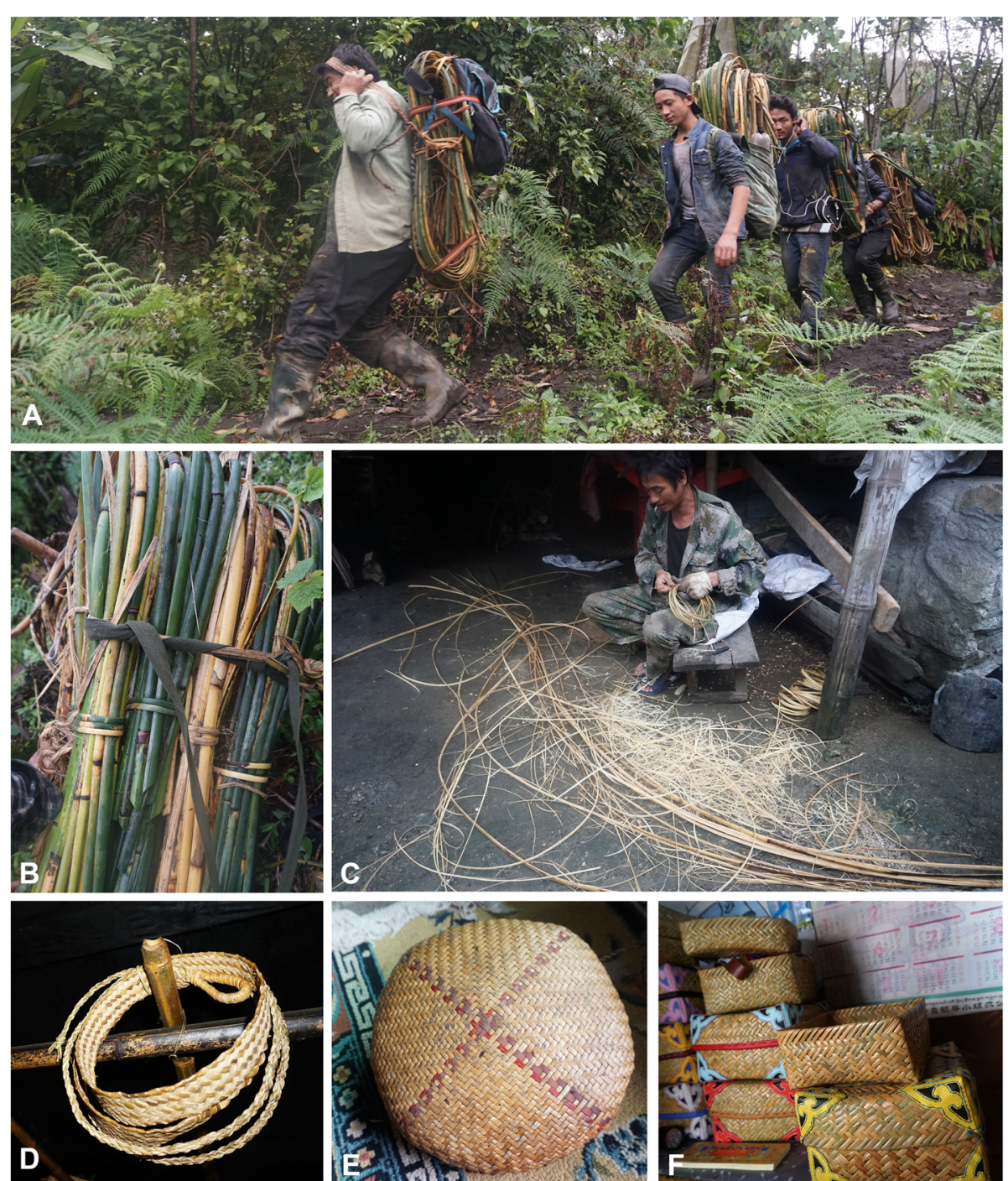

Fig. 6 Rattan as a basketry resource. a Men returning to their village with bundles of Calamus acanthospathus stems. b Details of harvested $C$. acanthospathus. c Splitting C. acanthospathus in preparation for weaving. d A woven rattan strap for a carrying basket. e. Completed winnowing basket. $\mathbf{f}$ Storage baskets

pinnata. The flowering period of Mussaenda pubescens is during June to July. The blooming period of Meliosma pinnata is during May to June [86]. The flowering time of these two species is exactly the same as maize planting time.

\section{Uses of endemic and near-endemic plant species}

Uses of endemic and near-endemic species in 12 plant families reflect the plant diversity of this part of the Indo-Burman biodiversity "hot-spot." Uses of these species have been rarely recorded in previous studies. In our field survey, we recorded the uses of narrowly distributed edible plants, for example, Arenga micrantha (used for starch), Hornstedtia tibetica (for fruits), Castanopsis clarkei, and Gnetum pendulum (for edible nuts) (Fig. 7a, d) and Ophiorrhiza medogensis (for vegetables). In contrast to the widespread use of the poisonous Derris trifoliolata (Leguminosae) containing rotenone, which occurs from East Africa to the Western Pacific, Monpa people use Derris scabricaulis which is endemic to Yunnan and Tibet. In terms of farming and equipment used by local households, agricultural tools are made from the high-density wood of Radermachera yunnanensis (Bignoniaceae) while wine strainers and implements for administering medicine are made from Dendrocalamus tibeticus (Poaceae). Litsea tibetana (Lauraceae) is a near endemic seed oil source, as are spices from the endemic 


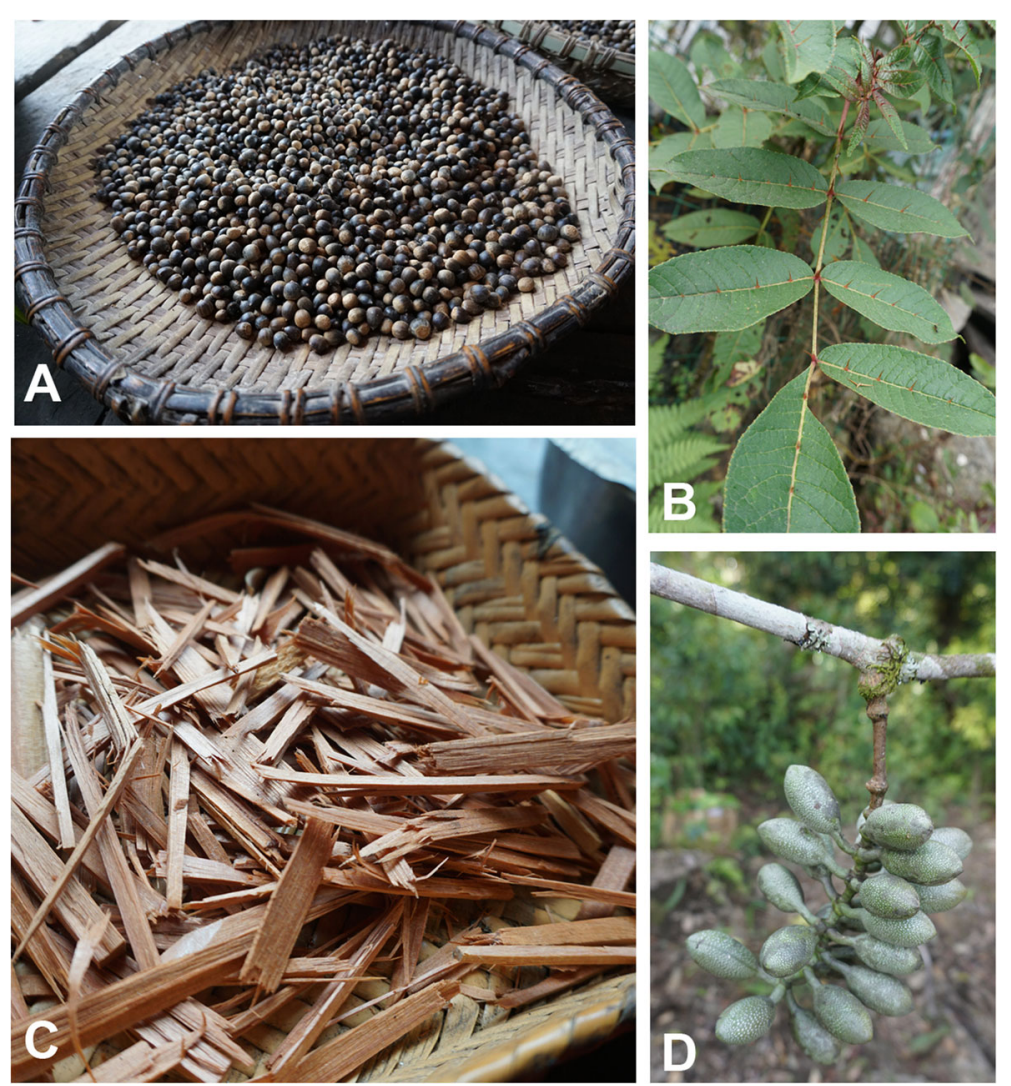

Fig. 7 Usual sources of food, spice and incense used by Monpa people. a Edible nuts from Castanopsis clarkei King ex Hook.f.. b Zanthoxylum motuoense C. C. Huang, a local source of spicy fruits. c Platycladus orientalis (L.) Franco wood used for incense. d Gnetum pendulum C. Y. Cheng., a near-endemic species with edible fruits

Zanthoxylum motuoense (Rutaceae). Additional unusual records are the use of Cinnamomum contractum (Lauraceae) as a tobacco substitute (a species only found in south-east Tibet and NW Yunnan, Morus wittiorum (Moraceae) fruits for medicine and the use of Garcinia nujiangensis (Clusiaceae), a species restricted to south-east Tibet, north-west, and west Yunnan for funeral rituals.

\section{How do plant uses reflect socio-economic change in Mêdog County?}

Until October 2013, there were no major roads in Mêdog County and Monpa people practised swidden agriculture, supplemented by hunting and gathering [87]. Despite the absence of roads, Monpa knowledge of plant uses reflect at least three categories of change.

Firstly, through oral history, knowledge of plants that Monpa ancestors would have encountered in Bhutan and Tibet prior to their migration to Mêdog. Secondly, a slow change in knowledge as introduced species were brought to Mêdog along the trade routes. These species include cereal crops from Africa (Eleusine coracana and Sorghum bicolor) and meso-America (Zea mays), cultivated fruits from north-west China (Prunus persica), medicinal plants from Africa (Ricinus communis) and North America (Datura stramonium), fuel from the Mediterranean Basin and the Middle East (Arundo donax), and three South American Solanceae that have come into "traditional" use (Nicotiana tabacum, Solanum americanum and Solanum aculeatissimum). Although oral histories do not indicate when these species were introduced, the fact that several introduced species are used ritually (maize, Eleusine coracana and Arundo donax) is one indication of early introductions. Another indication is the "traditional" medicinal use of introduced medicinal plants such as Datura stramonium (Fig. 8). Although $D$. stramonium seeds are known to be used for treating toothache elsewhere [88], but the method of preparation and administration used by Monpa people is innovative (Fig. 8a-d). Thirdly, in contrast to these "slow changes," there is "fast 

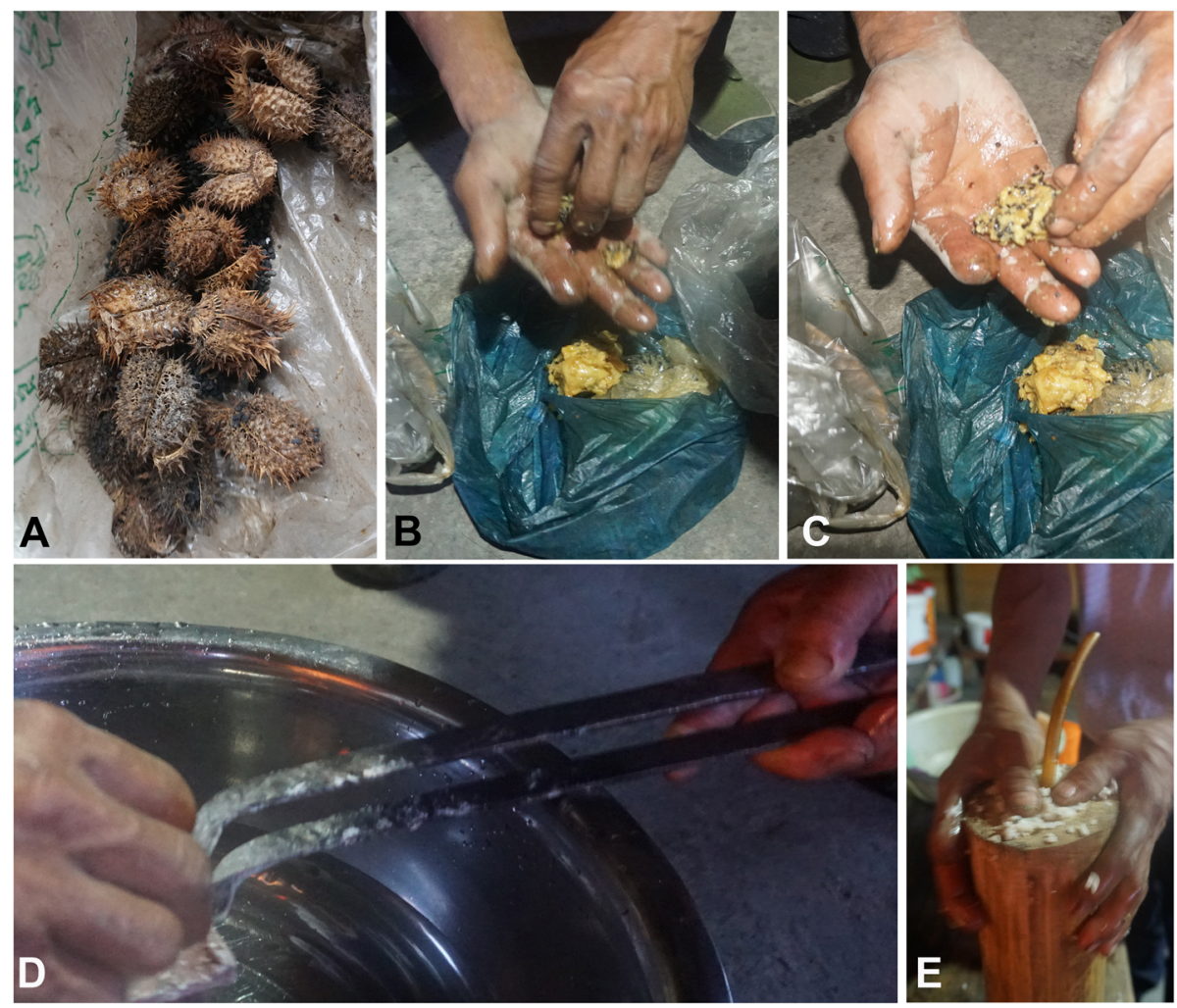

Fig. 8 Experimentation and use of an introduced species in Monpa "traditional" medicine. a Datura stramonium fruits. The seeds are used to treat toothache. b, c Mixing D. stramonium seeds with pig fat. $\mathbf{d}$ Creating hot steam by placing a red hot iron in water, on which the Datura seed/fat mixture is placed. e Dendrocalamus tibeticus bamboo culm, sealed using rice around a protruding tube that is placed over the super-heated Datura and pig-fat infused steam to direct the ingredients to the sore tooth and remove the "insect" causing toothache

change" over the past decade that has speeded up rapidly since the highway was opened in October 2013. This is reflected in changes in traditional architecture and in trade in selected plant resources (such as Dendrobium and Paris to China's TCM markets).

While Monpa people still have a wealth of ethnobotanical knowledge that has been passed down orally from generation to generation, the construction of a highway to Mêdog County has stimulated rapid change and possible loss of traditional knowledge. The influence of modernization, social and economic development, and the lack of interests shown by the young generation are seriously threatened to the ethnic culture of no written words [89]. Our research shows that the increasing publicity and availability of Tibetan and Chinese medicines has also affected the indigenous knowledge of the Monpa. There are no exclusive traditional doctors in the villages now and traditional medical knowledge is about to disappear.

\section{Conclusions}

Monpa traditional plant-based knowledge are practiced, accumulated, and passed down from generation to generation. The Monpa people in Mêdog County still preserve most of traditional plant-based knowledge. We documented 194 wild plant species belonging to 82 families 158 genera used for traditional medicines, food, dyeing, timber, religion, and other purposes during our ethnobotanical survey. Overall, this study provides a deeper understanding of the Monpa traditional knowledge on wild plants. The study suggests some wild medical plant species might have new active ingredients which are necessitated for further investigation. Since the development of modernization has changed the Monpa lifestyle and production structure, traditional knowledge and biocultural diversity can be essential components to ensure the sustainable development of Monpa community and may play a significant role in the sustainable use and development of Tibetan plant resources. 


\section{Appendix}

Table 4 Ethnobotanical inventory of Monpa in Mêdog County, Tibet, China

\begin{tabular}{|c|c|c|c|c|c|c|c|c|}
\hline Family name & Scientific name & $\begin{array}{l}\text { Vernacular } \\
\text { name }\end{array}$ & Habit & Parts used & Local use & $f$ & $\mathrm{Cl}$ & $\begin{array}{l}\text { Voucher } \\
\text { specimen } \\
\text { number }\end{array}$ \\
\hline Acanthaceae & $\begin{array}{l}\text { Strobilanthes cusia } \\
\text { (Nees) Kuntze }\end{array}$ & $\begin{array}{l}\text { Yang-shar- } \\
\text { pa }\end{array}$ & Herb & Leaves & Dye plant & 0.25 & 0.25 & WangYH0009 \\
\hline Actinidiaceae & $\begin{array}{l}\text { Saurauia punduana } \\
\text { Wall. }\end{array}$ & A-rong-ma & Tree & $\begin{array}{l}\text { Flower } \\
\text { buds and } \\
\text { fruits }\end{array}$ & Food (a kind of fruit) & 0.78 & 0.78 & $18 \mathrm{CS} 16811$ \\
\hline Adoxaceae & $\begin{array}{l}\text { Sambucus williamsii } \\
\text { Hance }\end{array}$ & $\begin{array}{l}\text { Bha-mu- } \\
\text { klung-shi }\end{array}$ & Shrub & Leaves & $\begin{array}{l}\text { Leaves are baked on the fire with butter } \\
\text { used for treating bruises }\end{array}$ & & & $18 \mathrm{CS} 16839$ \\
\hline Adoxaceae & $\begin{array}{l}\text { Viburnum } \\
\text { cylindricum Buch.- } \\
\text { Ham. ex D. Don }\end{array}$ & $\begin{array}{l}\text { Uh-mu- } \\
\text { ling-shing }\end{array}$ & Tree & $\begin{array}{l}\text { Fruits and } \\
\text { burgeons }\end{array}$ & $\begin{array}{l}\text { Fruit oil soaked in alcohol for anti- } \\
\text { inflammatory and soaked in honey for re- } \\
\text { moving scar. Burgeons are boiled in water } \\
\text { for repelling flea }\end{array}$ & 0.05 & 0.05 & $18 \mathrm{CS} 16894$ \\
\hline Adoxaceae & $\begin{array}{l}\text { Viburnum } \\
\text { erubescens Wall. }\end{array}$ & $\begin{array}{l}\text { Tseh-za- } \\
\text { klu-shing }\end{array}$ & Tree & Fruits & Food (a kind of fruit) & & & $18 \mathrm{CS} 16949$ \\
\hline Altingiaceae & $\begin{array}{l}\text { Altingia excelsa } \\
\text { Noronha }\end{array}$ & Sang-shing & Tree & $\begin{array}{l}\text { Branches, } \\
\text { fruits and } \\
\text { burgeons }\end{array}$ & $\begin{array}{l}\text { Fuel. Fruits are burned for refreshing. Making } \\
\text { tea }\end{array}$ & 0.53 & 0.53 & $18 \mathrm{CS} 16869$ \\
\hline Amaranthaceae & $\begin{array}{l}\text { Chenopodium } \\
\text { album L. }\end{array}$ & Shar-ri-mu & Herb & Seeds & Food (extracting starch) & 0.09 & 0.09 & $18 \mathrm{CS} 16857$ \\
\hline Anacardiaceae & $\begin{array}{l}\text { Choerospondias } \\
\text { axillaris (Roxb.) B. L. } \\
\text { Burtt \& A. W. Hill }\end{array}$ & Ju-ru-ra & Tree & Fruits & Food (a kind of fruit) & 0.16 & 0.16 & $18 \mathrm{CS} 16940$ \\
\hline Apiaceae & $\begin{array}{l}\text { Pimpinella } \\
\text { diversifolia DC. }\end{array}$ & $\begin{array}{l}\text { Gya-ma- } \\
\text { ga-dsa }\end{array}$ & Herb & $\begin{array}{l}\text { Whole } \\
\text { plant }\end{array}$ & Food (a kind of vegetable) & 0.56 & 0.56 & $18 \mathrm{CS} 16816$ \\
\hline Apocynaceae & Apocynaceae sp. & Nu-ru & Vine & $\begin{array}{l}\text { Roots and } \\
\text { stems }\end{array}$ & Medicine used for treating allergy & & & 18CS16899 \\
\hline Araceae & $\begin{array}{l}\text { Alocasia longiloba } \\
\text { Miq. }\end{array}$ & $\begin{array}{l}\text { Bo-zong- } \\
\text { gang-gyi- } \\
\text { pa }\end{array}$ & Herb & Roots & $\begin{array}{l}\text { Sliced roots used for anti-infective and treat- } \\
\text { ing burns }\end{array}$ & & & WangYH0069 \\
\hline Araceae & $\begin{array}{l}\text { Colocasia affinis } \\
\text { Schott }\end{array}$ & Bu-dong & Herb & Rhizomes & Food (a kind of vegetable). Extracting starch & 0.17 & 0.17 & $18 C S 16922$ \\
\hline Araceae & $\begin{array}{l}\text { Colocasia } \\
\text { antiquorum Schott }\end{array}$ & Bu-rong & Herb & $\begin{array}{l}\text { Whole } \\
\text { plant }\end{array}$ & Food (a kind of vegetable). Extracting starch & 0.11 & 0.11 & $18 \mathrm{CS} 16824$ \\
\hline Araceae & $\begin{array}{l}\text { Colocasia esculenta } \\
\text { (L.) Schott }\end{array}$ & Pon-song & Herb & $\begin{array}{l}\text { Whole } \\
\text { plant }\end{array}$ & Food (a kind of vegetable). Extracting starch & 0.05 & 0.05 & WangYH0184 \\
\hline Araceae & $\begin{array}{l}\text { Remusatia pumila } \\
\text { (D. Don) H. Li \& A. } \\
\text { Hay }\end{array}$ & Pon-song & Herb & $\begin{array}{l}\text { Whole } \\
\text { plant }\end{array}$ & $\begin{array}{l}\text { Food (a kind of vegetable, and boiled in the } \\
\text { water) }\end{array}$ & 0.05 & 0.05 & WangYH0029 \\
\hline Araceae & $\begin{array}{l}\text { Remusatia vivipara } \\
\text { (Roxb.) Schott }\end{array}$ & $\begin{array}{l}\text { Ri-bo- } \\
\text { srong }\end{array}$ & Herb & Leaves & $\begin{array}{l}\text { Food (a kind of vegetable, and boiled in the } \\
\text { water) }\end{array}$ & & & WangYH0178 \\
\hline Araceae & $\begin{array}{l}\text { Sauromatum } \\
\text { venosum (Dryand. } \\
\text { ex Aiton) Kunth }\end{array}$ & $\begin{array}{l}\text { Reh- } \\
\text { drong-ma }\end{array}$ & Herb & $\begin{array}{l}\text { Whole } \\
\text { plant }\end{array}$ & $\begin{array}{l}\text { Crushed plants are used for treating } \\
\text { suppuration }\end{array}$ & & & $18 C S 16876$ \\
\hline Araliaceae & $\begin{array}{l}\text { Brassaiopsis hainla } \\
\text { (Buch.-Ham.) Seem. }\end{array}$ & $\begin{array}{l}\text { Bhong- } \\
\text { dong- } \\
\text { shing }\end{array}$ & Tree & Barks & Boiled for treating arthritis & 0.05 & 0.05 & $18 \mathrm{CS} 16883$ \\
\hline Araliaceae & $\begin{array}{l}\text { Hydrocotyle } \\
\text { javanica Thunb. }\end{array}$ & $\begin{array}{l}\text { Sa-la- } \\
\text { meng-ba- } \\
\text { ren }\end{array}$ & Herb & $\begin{array}{l}\text { Whole } \\
\text { plant }\end{array}$ & Fish poison plant & 0.06 & 0.06 & $18 C S 16948$ \\
\hline Araliaceae & $\begin{array}{l}\text { Schefflera khasiana } \\
\text { (C. B. Clarke) R. Vig. }\end{array}$ & Pyu-shing & Tree & Stems & Musical instrument & 0.22 & 0.22 & $18 \mathrm{CS} 16897$ \\
\hline Arecaceae & $\begin{array}{l}\text { Arenga micrantha } \\
\text { C. F. Wei }\end{array}$ & Ta-shi & Tree & Stems & Food (extracting starch). Forage & 0.34 & 0.36 & $18 \mathrm{CS} 16836$ \\
\hline Arecaceae & Arenga pinnata & Ta-shing & Tree & Stems & Extracting starch & 0.16 & 0.16 & WangYH0132 \\
\hline
\end{tabular}


Table 4 Ethnobotanical inventory of Monpa in Mêdog County, Tibet, China (Continued)

\begin{tabular}{|c|c|c|c|c|c|c|c|c|}
\hline Family name & Scientific name & $\begin{array}{l}\text { Vernacular } \\
\text { name }\end{array}$ & Habit & Parts used & Local use & $f$ & $\mathrm{Cl}$ & $\begin{array}{l}\text { Voucher } \\
\text { specimen } \\
\text { number }\end{array}$ \\
\hline & (Wurmb) Merr. & & & & & & & \\
\hline Arecaceae & $\begin{array}{l}\text { Calamus } \\
\text { acanthospathus } \\
\text { Griff. }\end{array}$ & $\begin{array}{l}\text { B-nyu-mu/ } \\
\text { Ba-ser }\end{array}$ & Vine & $\begin{array}{l}\text { Burgeons } \\
\text { and fruits }\end{array}$ & $\begin{array}{l}\text { Food (a kind of vegetable and fruit). Making } \\
\text { agriculture tools }\end{array}$ & 0.43 & 0.43 & $18 \mathrm{CS} 16864$ \\
\hline Arecaceae & $\begin{array}{l}\text { Caryota obtusa } \\
\text { Griff. }\end{array}$ & Chu-shing & Tree & Stems & Making chopsticks & 0.09 & 0.09 & $18 \mathrm{CS} 16819$ \\
\hline Asparagaceae & $\begin{array}{l}\text { Polygonatum } \\
\text { oppositifolium } \\
\text { (Wall.) Royle }\end{array}$ & $\begin{array}{l}\text { Ren-gyi- } \\
\text { tsong }\end{array}$ & Herb & Burgeons & Food (a kind of vegetable) & 0.05 & 0.05 & WangYH0194 \\
\hline Asparagaceae & $\begin{array}{l}\text { Rohdea nepalensis } \\
\text { (Raf.) N.Tanaka }\end{array}$ & Ka-lu & Herb & $\begin{array}{l}\text { Tender } \\
\text { stems }\end{array}$ & Food (a kind of vegetable) & & & $18 \mathrm{CS} 16958$ \\
\hline Athyriaceae & $\begin{array}{l}\text { Diplazium } \\
\text { esculentum (Retz.) } \\
\text { Sw. }\end{array}$ & Ta-wai & Fern & $\begin{array}{l}\text { Tender } \\
\text { stems and } \\
\text { leaves }\end{array}$ & Food (a kind of vegetable) & 0.34 & 0.34 & $18 \mathrm{CS} 16817$ \\
\hline Balsaminaceae & $\begin{array}{l}\text { Impatiens arguta } \\
\text { Hook.f. \& Thomson }\end{array}$ & $\begin{array}{l}\text { Gyang- } \\
\text { tsong- } \\
\text { hwen }\end{array}$ & Herb & Leaves & $\begin{array}{l}\text { Crushed leaves are used for stopping } \\
\text { bleeding. Forage }\end{array}$ & 0.33 & 0.33 & WangYH0050 \\
\hline Begoniaceae & $\begin{array}{l}\text { Begonia aborensis } \\
\text { Dunn }\end{array}$ & Gyu-bu & Herb & Stems & Food (a kind of vegetable) & 0.08 & 0.08 & $18 \mathrm{CS} 16834$ \\
\hline Begoniaceae & $\begin{array}{l}\text { Begonia acetosella } \\
\text { Craib }\end{array}$ & Pa-pa-man & Herb & Leaves & $\begin{array}{l}\text { Mashed leaves are used for treating leeches } \\
\text { bite }\end{array}$ & & & $18 \mathrm{CS} 16936$ \\
\hline Berberidaceae & $\begin{array}{l}\text { Holboellia latifolia } \\
\text { Wall. }\end{array}$ & $\begin{array}{l}\text { Chou- } \\
\text { dang-lie-si }\end{array}$ & Vine & Fruits & Food (a kind of fruit) & 0.2 & 0.2 & $18 \mathrm{CS} 16898$ \\
\hline Bignoniaceae & $\begin{array}{l}\text { Radermachera } \\
\text { yunnanensis C.Y.Wu }\end{array}$ & $\begin{array}{l}\text { Gya-srong- } \\
\text { ni-shing }\end{array}$ & Tree & Stems & Making agriculture tools & 0.08 & 0.08 & $18 \mathrm{CS} 16944$ \\
\hline Boraginaceae & $\begin{array}{l}\text { Cordia dichotoma } \\
\text { G. Forst. }\end{array}$ & $\begin{array}{l}\text { Pa-mi- } \\
\text { shing }\end{array}$ & Tree & Fruits & Extracting oil & 0.13 & 0.13 & $18 \mathrm{CS} 16818$ \\
\hline Brassicaceae & $\begin{array}{l}\text { Cardamine } \\
\text { macrophylla Willd. }\end{array}$ & Shu & Herb & $\begin{array}{l}\text { Whole } \\
\text { plant }\end{array}$ & Food (a kind of vegetable) & & & $18 \mathrm{CS} 16852$ \\
\hline Brassicaceae & $\begin{array}{l}\text { Rorippa dubia } \\
\text { (Pers.) H.Hara }\end{array}$ & $\begin{array}{l}\text { Ling-zong- } \\
\text { mer-mu }\end{array}$ & Herb & $\begin{array}{l}\text { Whole } \\
\text { plant }\end{array}$ & Food (a kind of vegetable) & 0.31 & 0.31 & $18 \mathrm{CS} 16835$ \\
\hline Campanulaceae & $\begin{array}{l}\text { Codonopsis affinis } \\
\text { Hook.f. \& Thomson }\end{array}$ & $\begin{array}{l}\text { Gyang- } \\
\text { phu-sen }\end{array}$ & Herb & Fruits & Spice plant & 0.27 & 0.27 & WangYH0037 \\
\hline Campanulaceae & $\begin{array}{l}\text { Codonopsis inflata } \\
\text { Hook.f. }\end{array}$ & $\begin{array}{l}\text { Gyang-hu- } \\
\text { ser }\end{array}$ & Vine & Fruits & Spices plant & 0.05 & 0.05 & WangYH0038 \\
\hline Cannabaceae & $\begin{array}{l}\text { Celtis tetrandra } \\
\text { Roxb. }\end{array}$ & $\begin{array}{l}\text { Long- } \\
\text { shing }\end{array}$ & Tree & Fruits & Food (a kind of fruit) & 0.2 & 0.2 & $18 \mathrm{CS} 16903$ \\
\hline Caprifoliaceae & $\begin{array}{l}\text { Leycesteria formosa } \\
\text { Wall. }\end{array}$ & $\begin{array}{l}\text { Pya-min- } \\
\text { mon }\end{array}$ & Shrub & Leaves & Medicine uesd for stopping bleeding & & & WangYH0170 \\
\hline Celastraceae & $\begin{array}{l}\text { Celastrus } \\
\text { glaucophyllus } \\
\text { Rehder \& E. H. } \\
\text { Wilson }\end{array}$ & Ling-shing & $\begin{array}{l}\text { Twining } \\
\text { shrub }\end{array}$ & Trunks & Timber plant & & & WangYH0048 \\
\hline Clusiaceae & $\begin{array}{l}\text { Garcinia } \\
\text { nujiangensis C. Y. } \\
\text { Wu \& Y. H. Li }\end{array}$ & $\begin{array}{l}\text { La-ga- } \\
\text { dong- } \\
\text { shing }\end{array}$ & Tree & $\begin{array}{l}\text { Fruits and } \\
\text { stems }\end{array}$ & Food (a kind of fruit). Fuel & & & $18 \mathrm{CS} 16931$ \\
\hline Clusiaceae & $\begin{array}{l}\text { Garcinia } \\
\text { pedunculata Roxb. } \\
\text { ex Buch.-Ham. }\end{array}$ & Kor-mang & Tree & Fruits & Food (a kind of fruit) & & & WangYH0027 \\
\hline Combretaceae & $\begin{array}{l}\text { Terminalia } \\
\text { myriocarpa Van } \\
\text { Heurck \& Müll. Arg. }\end{array}$ & $\begin{array}{l}\text { Ba-lem- } \\
\text { shing }\end{array}$ & Tree & Trunks & Timber plant & & & WangYH0124 \\
\hline Commelinaceae & $\begin{array}{l}\text { Streptolirion volubile } \\
\text { Edgew. }\end{array}$ & Pa-ner-ju & Herb & $\begin{array}{l}\text { Whole } \\
\text { plant }\end{array}$ & Forage & & & $18 \mathrm{CS} 16885$ \\
\hline
\end{tabular}


Table 4 Ethnobotanical inventory of Monpa in Mêdog County, Tibet, China (Continued)

\begin{tabular}{|c|c|c|c|c|c|c|c|c|}
\hline Family name & Scientific name & $\begin{array}{l}\text { Vernacular } \\
\text { name }\end{array}$ & Habit & Parts used & Local use & $f$ & $\mathrm{Cl}$ & $\begin{array}{l}\text { Voucher } \\
\text { specimen } \\
\text { number }\end{array}$ \\
\hline Compositae & $\begin{array}{l}\text { Acmella oleracea } \\
\text { (L.) R. K. Jansen }\end{array}$ & Nyi-ra-ki & Herb & Burgeons & Food (a kind of vegetable) & 0.13 & 0.13 & WangYH0056 \\
\hline Compositae & $\begin{array}{l}\text { Artemisia vestita } \\
\text { Wall. ex Besser }\end{array}$ & $\begin{array}{l}\text { Myer-rang- } \\
\text { ma }\end{array}$ & Herb & Leaves & $\begin{array}{l}\text { The powder of "xin zei" are wrapped in } \\
\text { leaves and rolled up, and then placed on } \\
\text { the navel as moxibustion, used for treating } \\
\text { stomach pain }\end{array}$ & & & $18 \mathrm{CS} 16868$ \\
\hline Compositae & Bidens pilosa $\mathrm{L}$. & $\begin{array}{l}\text { Sgrong- } \\
\text { treng-rong }\end{array}$ & Herb & Leaves & $\begin{array}{l}\text { Boiled leaves used for treating cold, sore } \\
\text { throat and stuffy nose }\end{array}$ & 0.05 & 0.05 & $18 \mathrm{CS} 16872$ \\
\hline Compositae & $\begin{array}{l}\text { Crassocephalum } \\
\text { crepidioides (Benth.) } \\
\text { S. Moore }\end{array}$ & $\begin{array}{l}\text { Gyal-pa- } \\
\text { ehn }\end{array}$ & Herb & $\begin{array}{l}\text { Whole } \\
\text { plant }\end{array}$ & Food (a kind of vegetable) & 0.78 & 0.78 & $18 \mathrm{CS} 16809$ \\
\hline Compositae & $\begin{array}{l}\text { Gynura procumbens } \\
\text { (Lour.) Merr. }\end{array}$ & $\begin{array}{l}\text { Wen-gya- } \\
\text { pa }\end{array}$ & Herb & $\begin{array}{l}\text { Aerial } \\
\text { parts }\end{array}$ & Forage & 0.06 & 0.06 & WangYH0121 \\
\hline Compositae & $\begin{array}{l}\text { Helianthus } \\
\text { tuberosus L. }\end{array}$ & Yang-gyal & Herb & Tubers & & & & $18 \mathrm{CS} 16854$ \\
\hline Cornaceae & $\begin{array}{l}\text { Cornus capitata } \\
\text { Wall. }\end{array}$ & $\begin{array}{l}\text { Da-ming- } \\
\text { der-shing }\end{array}$ & Tree & Fruits & Food (a kind of fruit) & 0.08 & 0.08 & $18 \mathrm{CS} 16950$ \\
\hline Cucurbitaceae & Cucurbitaceae sp. & Doe-shung & Vine & Tubers & Washing hair and clothes & 0.19 & 0.19 & $18 \mathrm{CS} 16823$ \\
\hline Cucurbitaceae & $\begin{array}{l}\text { Momordica dioica } \\
\text { Roxb. ex Willd. }\end{array}$ & Su-ba & Herb & Leaves & $\begin{array}{l}\text { Food (a kind of vegetable), boiled leaves } \\
\text { used for treatinng cholecystitis. Washing hair } \\
\text { and clothes }\end{array}$ & 0.31 & 0.31 & $18 \mathrm{CS} 16874$ \\
\hline Cucurbitaceae & $\begin{array}{l}\text { Solena heterophylla } \\
\text { Lour. }\end{array}$ & $\begin{array}{l}\text { Gang-gu- } \\
\text { long }\end{array}$ & Herb & Fruits & Food (a kind of fruit) & 0.25 & 0.25 & $18 \mathrm{CS} 16873$ \\
\hline Cucurbitaceae & $\begin{array}{l}\text { Thladiantha } \\
\text { cordifolia (Blume) } \\
\text { Cogn. }\end{array}$ & Su-pa & Vine & Tubers & Washing hair and clothes & 0.34 & 0.34 & $18 \mathrm{CS} 16863$ \\
\hline Cucurbitaceae & $\begin{array}{l}\text { Trichosanthes } \\
\text { tricuspidata Lour. }\end{array}$ & A-pa-kas & Vine & Seeds & Food (a kind of vegetable) & 0.06 & 0.06 & $18 \mathrm{CS} 16943$ \\
\hline Cucurbitaceae & $\begin{array}{l}\text { Zehneria japonica } \\
\text { (Thunb.) H.Y. Liu }\end{array}$ & Ka-gyi & Herb & $\begin{array}{l}\text { Whole } \\
\text { plant }\end{array}$ & Food (a kind of vegetable) & 0.19 & 0.19 & $18 \mathrm{CS} 16826$ \\
\hline Cupressaceae & $\begin{array}{l}\text { Platycladus } \\
\text { orientalis (L.) Franco }\end{array}$ & shug-pa & Tree & Stems & Religious ritual use & & & WangYH0017 \\
\hline Cyatheaceae & $\begin{array}{l}\text { Alsophila articulata } \\
\text { J. Sm. ex T. Moore } \\
\text { \& Houlston }\end{array}$ & A-gyi & Tree & Stems & Making alcohol beverages. Extracting starch & 0.16 & 0.18 & WangYH0108 \\
\hline Cyperaceae & $\begin{array}{l}\text { Scirpus rosthornii } \\
\text { Diels }\end{array}$ & $\begin{array}{l}\text { Gong-bu- } \\
\text { ueh }\end{array}$ & Herb & Fruits & Food (a kind of fruit) & 0.06 & 0.06 & $18 \mathrm{CS} 16946$ \\
\hline Dioscoreaceae & Dioscorea alata $\mathrm{L}$. & $\begin{array}{l}\text { Dgro-ton/ } \\
\text { Gyu-dang }\end{array}$ & Vine & Rhizomes & Food (a kind of vegetable). Extracting starch & 0.08 & 0.08 & WangYH0140 \\
\hline Dioscoreaceae & $\begin{array}{l}\text { Dioscorea } \\
\text { melanophyma Prain } \\
\text { \& Burkill }\end{array}$ & $\begin{array}{l}\text { Bo-zon-za- } \\
\text { lu }\end{array}$ & Vine & $\begin{array}{l}\text { Leaves } \\
\text { and } \\
\text { rhizomes }\end{array}$ & $\begin{array}{l}\text { Food (a kind of vegetable). Extracting starch. } \\
\text { Forage }\end{array}$ & 0.06 & 0.06 & WangYH0059 \\
\hline Dioscoreaceae & $\begin{array}{l}\text { Dioscorea } \\
\text { pentaphylla L. }\end{array}$ & Pan-dang & Vine & Roots & $\begin{array}{l}\text { Extracting starch. Forage. Food (a kind of } \\
\text { fruit) }\end{array}$ & 0.34 & 0.34 & $18 \mathrm{CS} 16889$ \\
\hline Dioscoreaceae & Dioscorea sp. & Ju-dang & Vine & Rhizomes & Food (a kind of vegetable). Extracting starch & 0.36 & 0.36 & $18 \mathrm{CS} 16877$ \\
\hline Ebenaceae & Diospyros lotus L. & $\begin{array}{l}\text { A-mu- } \\
\text { dong-ba- } \\
\text { shing }\end{array}$ & Tree & Fruits & Food (a kind of fruit) & & & $18 \mathrm{CS} 16954$ \\
\hline Ebenaceae & $\begin{array}{l}\text { Diospyros variegata } \\
\text { Kurz }\end{array}$ & $\begin{array}{l}\text { Ang-dri- } \\
\text { pha }\end{array}$ & Shrub & Fruits & Food (a kind of fruit) & & & WangYH0104 \\
\hline Elaeagnaceae & $\begin{array}{l}\text { Elaeagnus conferta } \\
\text { Roxb. }\end{array}$ & $\begin{array}{l}\text { Trong-pa- } \\
\text { lin }\end{array}$ & Shrub & Fruits & Food (a kind of fruit) & & & 18CS16952 \\
\hline Elaeagnaceae & Elaeagnus & Dar-ma & Shrub & Fruits & Food (a kind of fruit) & 0.27 & 0.27 & 18CS16859 \\
\hline
\end{tabular}


Table 4 Ethnobotanical inventory of Monpa in Mêdog County, Tibet, China (Continued)

\begin{tabular}{|c|c|c|c|c|c|c|c|c|}
\hline Family name & Scientific name & $\begin{array}{l}\text { Vernacular } \\
\text { name }\end{array}$ & Habit & Parts used & Local use & $f$ & $\mathrm{Cl}$ & $\begin{array}{l}\text { Voucher } \\
\text { specimen } \\
\text { number }\end{array}$ \\
\hline & umbellata Thunb. & & & & & & & \\
\hline Elaeocarpaceae & $\begin{array}{l}\text { Elaeocarpus } \\
\text { braceanus Watt ex } \\
\text { C. B. Clarke }\end{array}$ & $\begin{array}{l}\text { Gar-shar- } \\
\text { dong- } \\
\text { shing }\end{array}$ & Tree & $\begin{array}{l}\text { Seeds and } \\
\text { fruits }\end{array}$ & $\begin{array}{l}\text { Boiled seeds used for treating diarrhea. } \\
\text { Food (a kind of fruit) }\end{array}$ & 0.5 & 0.5 & $18 \mathrm{CS} 16858$ \\
\hline Elaeocarpaceae & Elaeocarpaceae sp. & $\begin{array}{l}\text { Dang-bu- } \\
\text { ru }\end{array}$ & $\begin{array}{l}\text { Tree or } \\
\text { shrub }\end{array}$ & Fruits & Extracting oil & 0.19 & 0.19 & $18 \mathrm{CS} 16942$ \\
\hline Equisetaceae & $\begin{array}{l}\text { Equisetum } \\
\text { ramosissimum Desf. }\end{array}$ & Nyer-tshyu & Herb & $\begin{array}{l}\text { Roots and } \\
\text { aerial parts }\end{array}$ & $\begin{array}{l}\text { Food (a kind of fruit). Boiled liquid for } \\
\text { treating rheumatism }\end{array}$ & 0.3 & 0.3 & $18 \mathrm{CS} 16878$ \\
\hline Ericaceae & $\begin{array}{l}\text { Craibiodendron } \\
\text { henryi W. W. Sm. }\end{array}$ & $\begin{array}{l}\text { Shar-kor- } \\
\text { shing }\end{array}$ & Tree & $\begin{array}{l}\text { Branches } \\
\text { and leaves }\end{array}$ & Put in the field for treating rice blast & & & $18 \mathrm{CS} 16890$ \\
\hline Ericaceae & $\begin{array}{l}\text { Gaultheria } \\
\text { straminea R. C. } \\
\text { Fang }\end{array}$ & $\begin{array}{l}\text { Tsong-pa- } \\
\text { ling }\end{array}$ & Shrub & Fruits & Food (a kind of fruit) & 0.08 & 0.08 & $18 \mathrm{CS} 16861$ \\
\hline Euphorbiaceae & $\begin{array}{l}\text { Macaranga } \\
\text { denticulata (Blume) } \\
\text { Müll.Arg. }\end{array}$ & Tsa-la-ga & Tree & Leaves & Making agriculture tools & & & 18CS16909 \\
\hline Euphorbiaceae & $\begin{array}{l}\text { Ostodes paniculata } \\
\text { Blume }\end{array}$ & $\begin{array}{l}\text { Ga-ren-de- } \\
\text { shing }\end{array}$ & Tree & Seeds & Extracting oil & 0.06 & 0.06 & $18 \mathrm{CS} 16840$ \\
\hline Euphorbiaceae & Ricinus communis L. & $\begin{array}{l}\text { Gyal-mu- } \\
\text { na }\end{array}$ & Herb & Leaves & $\begin{array}{l}\text { Leaves are baked on the fire with butter } \\
\text { used for treating bruises. Seed oils }\end{array}$ & & & $18 \mathrm{CS} 16888$ \\
\hline Fagaceae & $\begin{array}{l}\text { Castanopsis clarkei } \\
\text { King ex Hook.f. }\end{array}$ & Suo-na & Tree & Fruits & Nut & 0.11 & 0.11 & $18 \mathrm{CS} 16938$ \\
\hline Gentianaceae & $\begin{array}{l}\text { Crawfurdia } \\
\text { angustata C. B. } \\
\text { Clarke }\end{array}$ & $\begin{array}{l}\text { Suo-long- } \\
\text { ma }\end{array}$ & Herb & $\begin{array}{l}\text { Leaves } \\
\text { and } \\
\text { flowers }\end{array}$ & Food (a kind of vegetable) & 0.09 & 0.09 & $18 \mathrm{CS} 16831$ \\
\hline Gentianaceae & $\begin{array}{l}\text { Swertia angustifolia } \\
\text { Buch.-Ham. ex D. } \\
\text { Don }\end{array}$ & $\begin{array}{l}\text { Pau-sein- } \\
\text { po }\end{array}$ & Herb & $\begin{array}{l}\text { Leaves } \\
\text { and roots }\end{array}$ & Medicine used for treating malaria & & & WangYH0023 \\
\hline Gentianaceae & $\begin{array}{l}\text { Swertia nervosa } \\
\text { (Wall. ex G. Don) C. } \\
\text { B. Clarke }\end{array}$ & $\begin{array}{l}\text { Pa-bhu- } \\
\text { ser-pu }\end{array}$ & Herb & $\begin{array}{l}\text { Leaves } \\
\text { and roots }\end{array}$ & $\begin{array}{l}\text { Leaves are boiled in the water used for } \\
\text { treating diarrhea }\end{array}$ & & & $18 \mathrm{CS} 16841$ \\
\hline Gnetaceae & $\begin{array}{l}\text { Gnetum pendulum } \\
\text { C. Y. Cheng }\end{array}$ & $\begin{array}{l}\text { Gyong-ga- } \\
\text { sa }\end{array}$ & Vine & Fruits & Nut & 0.22 & 0.22 & $18 C S 16959$ \\
\hline Hydrangeaceae & $\begin{array}{l}\text { Dichroa febrifuga } \\
\text { Lour. }\end{array}$ & $\begin{array}{l}\text { Yo-gor- } \\
\text { shing }\end{array}$ & Shrub & Branches & Branches are burned as mosquito repellent & & & 18CS16901 \\
\hline Hypericaceae & $\begin{array}{l}\text { Hypericum bellum } \\
\text { H. L. Li }\end{array}$ & $\begin{array}{l}\text { Kor-ma- } \\
\text { shing }\end{array}$ & Shrub & Fruits & Food (sweet taste) & & & WangYH0110 \\
\hline Hypoxidaceae & $\begin{array}{l}\text { Molineria capitulata } \\
\text { (Lour.) Herb. }\end{array}$ & Tsan-ngan & Herb & Fruits & Food (a kind of fruit) & 0.27 & 0.27 & $18 \mathrm{CS} 16829$ \\
\hline Lamiaceae & $\begin{array}{l}\text { Elsholtzia blanda } \\
\text { (Benth.) Benth. }\end{array}$ & $\begin{array}{l}\text { Na-gang- } \\
\text { shing }\end{array}$ & Herb & $\begin{array}{l}\text { Aerial } \\
\text { parts }\end{array}$ & Incense plant & & & WangYH0071 \\
\hline Lamiaceae & $\begin{array}{l}\text { Elsholtzia feddei } \\
\text { H.Lév. }\end{array}$ & Pa-pi & Herb & Leaves & Spice plant for making blood sausage & & & $18 \mathrm{CS} 16882$ \\
\hline Lamiaceae & $\begin{array}{l}\text { Isodon } \\
\text { lophanthoides } \\
\text { (Buch.-Ham. ex } \\
\text { D.Don) H.Hara }\end{array}$ & $\begin{array}{l}\text { Ra-khu-la- } \\
\text { dang }\end{array}$ & Herb & $\begin{array}{l}\text { Whole } \\
\text { plant }\end{array}$ & Boiled liquid for treating intestinal parasites & & & WangYH0172 \\
\hline Lamiaceae & $\begin{array}{l}\text { Mosla dianthera } \\
\text { (Buch.-Ham. ex } \\
\text { Roxb.) Maxim. }\end{array}$ & $\begin{array}{l}\text { Shing- } \\
\text { nang-gu-lu }\end{array}$ & Herb & Leaves & Chewed leaves used for treating allergies & & & $18 \mathrm{CS} 16871$ \\
\hline Lamiaceae & $\begin{array}{l}\text { Perilla frutescens (L.) } \\
\text { Britton }\end{array}$ & Nang & Herb & Seeds & Extracting oil & 0.08 & 0.08 & WangYH0199 \\
\hline Lamiaceae & $\begin{array}{l}\text { Pogostemon } \\
\text { brevicorollus Y.Z.Sun }\end{array}$ & $\begin{array}{l}\text { Na-mu- } \\
\text { sein }\end{array}$ & Herb & $\begin{array}{l}\text { Whole } \\
\text { plant }\end{array}$ & Food (a kind of vegetable) & 0.2 & 0.2 & $18 \mathrm{CS} 16865$ \\
\hline
\end{tabular}


Table 4 Ethnobotanical inventory of Monpa in Mêdog County, Tibet, China (Continued)

\begin{tabular}{|c|c|c|c|c|c|c|c|c|}
\hline Family name & Scientific name & $\begin{array}{l}\text { Vernacular } \\
\text { name }\end{array}$ & Habit & Parts used & Local use & $f$ & $\mathrm{Cl}$ & $\begin{array}{l}\text { Voucher } \\
\text { specimen } \\
\text { number }\end{array}$ \\
\hline Lauraceae & $\begin{array}{l}\text { Cinnamomum } \\
\text { contractum H. W. Li }\end{array}$ & Shing-tsa & Tree & Roots & $\begin{array}{l}\text { Crushed roots are used for stomach pain. } \\
\text { Tobacco substitutes }\end{array}$ & 0.28 & 0.28 & 18CS16892 \\
\hline Lauraceae & $\begin{array}{l}\text { Cinnamomum iners } \\
\text { Reinw. ex Blume }\end{array}$ & $\begin{array}{l}\text { Lho-pa- } \\
\text { sang-shing }\end{array}$ & Tree & Leaves & Incense plant & 0.06 & 0.06 & WangYH0030 \\
\hline Lauraceae & $\begin{array}{l}\text { Litsea tibetana Yen } \\
\text { C. Yang \& P. H. } \\
\text { Huang }\end{array}$ & $\begin{array}{l}\text { Snying- } \\
\text { shing }\end{array}$ & Shrub & Fruits & Extracting oil & 0.09 & 0.09 & $18 \mathrm{CS} 16934$ \\
\hline Leguminosae & $\begin{array}{l}\text { Amphicarpaea } \\
\text { bracteata subsp. } \\
\text { edgeworthii } \\
\text { (Benth.) H.Ohashi }\end{array}$ & Shor-ru & Herb & Roots & Forage & & & WangYH0094 \\
\hline Leguminosae & $\begin{array}{l}\text { Derris scabricaulis } \\
\text { (Franch.) Gagnep. }\end{array}$ & Ang-du-ru & Liana & Roots & Fish poison plant & 0.16 & 0.16 & $18 \mathrm{CS} 16821$ \\
\hline Leguminosae & $\begin{array}{l}\text { Erythrina } \\
\text { arborescens Roxb. }\end{array}$ & Tsa-shing & Tree & $\begin{array}{l}\text { Stems and } \\
\text { leaves }\end{array}$ & $\begin{array}{l}\text { Stems are used for carving materials. Making } \\
\text { agriculture tools }\end{array}$ & 0.25 & 0.32 & $18 \mathrm{CS} 16891$ \\
\hline Leguminosae & $\begin{array}{l}\text { Entada rheedii } \\
\text { Spreng. }\end{array}$ & $\begin{array}{l}\text { Kor-lo-ba- } \\
\text { ru }\end{array}$ & Vine & Fruits & Food (remove toxicity by boiling 10 times) & 0.22 & 0.22 & $18 \mathrm{CS} 16846$ \\
\hline Leguminosae & $\begin{array}{l}\text { Millettia pachycarpa } \\
\text { Benth. }\end{array}$ & Ngra-ru & Liana & $\begin{array}{l}\text { Seeds and } \\
\text { roots }\end{array}$ & $\begin{array}{l}\text { Crushed seeds and roots are used for killing } \\
\text { insects }\end{array}$ & & & WangYH0061 \\
\hline Loranthaceae & $\begin{array}{l}\text { Tripodanthus } \\
\text { acutifolius (Ruiz \& } \\
\text { Pav.) Tiegh. }\end{array}$ & Tsa-snying & $\begin{array}{l}\text { Shrub } \\
\text { parasitic }\end{array}$ & Fruits & Food (a kind of fruit) & & & $18 \mathrm{CS} 16928$ \\
\hline Malvaceae & $\begin{array}{l}\text { Abroma augusta } \\
\text { (L.) L.f. }\end{array}$ & $\begin{array}{l}\text { Go-men- } \\
\text { ta-dong- } \\
\text { shing }\end{array}$ & Shrub & $\begin{array}{l}\text { Whole } \\
\text { plant }\end{array}$ & Making agriculture tools & 0.06 & 0.06 & WangYH0OO3 \\
\hline Malvaceae & Malvaceae sp. & $\begin{array}{l}\text { Pu-lang- } \\
\text { shing }\end{array}$ & Tree & Fruits & Food (a kind of fruit) & 0.06 & 0.06 & $18 \mathrm{CS} 16827$ \\
\hline Malvaceae & $\begin{array}{l}\text { Sterculia lanceifolia } \\
\text { Roxb. }\end{array}$ & $\begin{array}{l}\text { Bha-ba-ba- } \\
\text { gu }\end{array}$ & $\begin{array}{l}\text { Tree or } \\
\text { shrub }\end{array}$ & Fruits & Food (a kind of fruit) & 0.23 & 0.23 & $18 \mathrm{CS} 16910$ \\
\hline Malvaceae & Urena lobata L. & $\begin{array}{l}\text { Tsi-ming- } \\
\text { uenh }\end{array}$ & Herb & $\begin{array}{l}\text { Whole } \\
\text { plant }\end{array}$ & Religious ritual use & 0.22 & 0.22 & $18 \mathrm{CS} 16893$ \\
\hline Marantaceae & $\begin{array}{l}\text { Stachyphrynium } \\
\text { placentarium (Lour.) } \\
\text { Clausager \& Borchs. }\end{array}$ & La-gu-la-la & Herb & Leaves & Making agriculture tools & & & WangYH0196 \\
\hline Melanthiaceae & Paris polyphylla ssp. & $\begin{array}{l}\text { A-du-ba- } \\
\text { du }\end{array}$ & Herb & Rhizomes & Boiled liquid for treating diabetes & & & $18 \mathrm{CS} 16853$ \\
\hline Menispermaceae & $\begin{array}{l}\text { Stephania } \\
\text { abyssinica (Quart.- } \\
\text { Dill. \& A.Rich.) Walp. }\end{array}$ & Ru-dour & $\begin{array}{l}\text { Woody } \\
\text { vine }\end{array}$ & Roots & $\begin{array}{l}\text { Boiled the dried roots used for treating } \\
\text { rheumatism and snake bite }\end{array}$ & & & WangYH0177 \\
\hline Menispermaceae & Stephania sp. & $\begin{array}{l}\text { Yong-ju- } \\
\text { pin }\end{array}$ & $\begin{array}{l}\text { Woody } \\
\text { vine }\end{array}$ & Fruits & Food (a kind of fruit) & 0.22 & 0.22 & 18CS16932 \\
\hline Moraceae & $\begin{array}{l}\text { Ficus auriculata } \\
\text { Lour. }\end{array}$ & $\begin{array}{l}\text { Ba-drong- } \\
\text { ma-shing }\end{array}$ & Tree & $\begin{array}{l}\text { Fruits and } \\
\text { leaves }\end{array}$ & Food (a kind of fruit). Forage & 0.06 & 0.08 & $18 \mathrm{CS} 16960$ \\
\hline Moraceae & $\begin{array}{l}\text { Ficus cyrtophylla } \\
\text { (Wall. ex Miq.) Miq. }\end{array}$ & Pa-ju-ma & $\begin{array}{l}\text { Tree or } \\
\text { shrub }\end{array}$ & Fruits & Beverage & & & 18CS16915 \\
\hline Moraceae & Ficus oligodon Miq. & $\begin{array}{l}\text { Ba-ler- } \\
\text { drong-ma }\end{array}$ & Tree & Fruits & Food (a kind of fruit) & 0.09 & 0.09 & $18 \mathrm{CS} 16918$ \\
\hline Moraceae & $\begin{array}{l}\text { Ficus semicordata } \\
\text { Buch.-Ham. ex Sm. }\end{array}$ & Drong-ma & Tree & $\begin{array}{l}\text { Fruits and } \\
\text { leaves }\end{array}$ & $\begin{array}{l}\text { Fruits are eaten directly. Leaves are used as } \\
\text { sandpaper to burnish the bowl }\end{array}$ & 0.39 & 0.43 & $18 \mathrm{CS} 16832$ \\
\hline Moraceae & $\begin{array}{l}\text { Ficus subincisa } \\
\text { Buch.-Ham. ex Sm. }\end{array}$ & $\begin{array}{l}\text { Rel-me- } \\
\text { sgrong-ma }\end{array}$ & Tree & Fruits & Food (a kind of fruit) & & & $18 \mathrm{CS} 16925$ \\
\hline Moraceae & Morus alba L. & $\begin{array}{l}\text { Sems-ling- } \\
\text { shing }\end{array}$ & Tree & Fruits & Food (a kind of fruit) & 0.17 & 0.17 & $18 \mathrm{CS} 16902$ \\
\hline
\end{tabular}


Table 4 Ethnobotanical inventory of Monpa in Mêdog County, Tibet, China (Continued)

\begin{tabular}{|c|c|c|c|c|c|c|c|c|}
\hline Family name & Scientific name & $\begin{array}{l}\text { Vernacular } \\
\text { name }\end{array}$ & Habit & Parts used & Local use & $f$ & $\mathrm{Cl}$ & $\begin{array}{l}\text { Voucher } \\
\text { specimen } \\
\text { number }\end{array}$ \\
\hline Moraceae & $\begin{array}{l}\text { Morus wittiorum } \\
\text { Hand.-Mazz. }\end{array}$ & $\begin{array}{l}\text { Sems-ling- } \\
\text { shing }\end{array}$ & Tree & Stems & $\begin{array}{l}\text { Boiled liquid for treating leprosy. Timber } \\
\text { plant }\end{array}$ & 0.25 & 0.25 & 18CS16947 \\
\hline Musaceae & $\begin{array}{l}\text { Musa sanguinea } \\
\text { Hook.f. }\end{array}$ & $\begin{array}{l}\text { A-nyi-lae- } \\
\text { sih }\end{array}$ & Herb & Fruits & Food (a kind of fruit) & 0.3 & 0.3 & WangYH0176 \\
\hline Nephrolepidaceae & $\begin{array}{l}\text { Nephrolepis } \\
\text { cordifolia (L.) C. } \\
\text { Presl }\end{array}$ & Ta-wai & Fern & Fruits & Food (a kind of fruit) & 0.33 & 0.33 & $18 \mathrm{CS} 16896$ \\
\hline Oleaceae & $\begin{array}{l}\text { Fraxinus floribunda } \\
\text { Wall. }\end{array}$ & $\begin{array}{l}\text { Tra-per- } \\
\text { shing }\end{array}$ & Tree & Barks & Boiled liquid for treating sprain and sunburn & & & 18CS16912 \\
\hline Omphalotaceae & $\begin{array}{l}\text { Lentinus sajor-caju } \\
\text { Fr. }\end{array}$ & $\begin{array}{l}\text { Bren-ba- } \\
\text { ba-mu }\end{array}$ & Fungi & Mushroom & Food (a kind of vegetable) & & & $18 \mathrm{CS} 16933$ \\
\hline Omphalotaceae & Lentinus sp. & $\begin{array}{l}\text { Tsyer-gen- } \\
\text { ba-mu }\end{array}$ & Fungi & Mushroom & Food (a kind of vegetable) & & & $18 \mathrm{CS} 16930$ \\
\hline Ophioglossaceae & $\begin{array}{l}\text { Ophioglossum } \\
\text { vulgatum L. }\end{array}$ & $\begin{array}{l}\text { Gu-gu- } \\
\text { meng }\end{array}$ & Grass & Burgeons & Food (a kind of vegetable) & 0.06 & 0.06 & $18 \mathrm{CS} 16844$ \\
\hline Orchidaceae & $\begin{array}{l}\text { Dendrobium } \\
\text { catenatum Lindl. }\end{array}$ & Shi-hu & $\begin{array}{l}\text { Herb } \\
\text { epiphytic }\end{array}$ & Stems & Boiled liquid for treating cold & & & $18 \mathrm{CS} 16856$ \\
\hline Oxalidaceae & Oxalis corniculata L. & $\begin{array}{l}\text { Ju-bu- } \\
\text { uenh }\end{array}$ & Herb & Leaves & $\begin{array}{l}\text { Eaten directly, used for treating morning } \\
\text { sickness }\end{array}$ & & & $18 \mathrm{CS} 16867$ \\
\hline Pentaphylacaceae & $\begin{array}{l}\text { Eurya acuminata } \\
\text { DC. }\end{array}$ & Zem-shing & $\begin{array}{l}\text { Tree or } \\
\text { shrub }\end{array}$ & Leaves & Dye plant and mordant & & & WangYH0067 \\
\hline Phytolaccaceae & $\begin{array}{l}\text { Phytolacca acinosa } \\
\text { Roxb. }\end{array}$ & $\begin{array}{l}\text { Mye-mye- } \\
\text { gang-pu- } \\
\text { mon }\end{array}$ & Herb & Leaves & Spice plant & 0.06 & 0.06 & 18CS16881 \\
\hline Pinaceae & $\begin{array}{l}\text { Pinus wallichiana } \\
\text { A.B.Jacks. }\end{array}$ & $\begin{array}{l}\text { Shog- } \\
\text { shing- } \\
\text { nang }\end{array}$ & Tree & Trunks & Timber plant & 0.2 & 0.2 & WangYH0128 \\
\hline Piperaceae & $\begin{array}{l}\text { Piper } \\
\text { semiimmersum C. } \\
\text { DC. }\end{array}$ & Pi-pi-ling & Climber & Leaves & $\begin{array}{l}\text { Boiled the dried leaves used for treating } \\
\text { altitude sickness and irregular menstruation }\end{array}$ & & & $18 \mathrm{CS} 16845$ \\
\hline Piperaceae & Piper sp. & Sa-pa & $\begin{array}{l}\text { Shrub or } \\
\text { climber }\end{array}$ & Leaves & Mashed leaves used for stopping bleeding & & & 18CS16822 \\
\hline Piperaceae & $\begin{array}{l}\text { Piper sylvaticum } \\
\text { Roxb. }\end{array}$ & Pang-ser & Climber & Leaves & Mashed leaves used for anti-inflammatory & & & WangYH0188 \\
\hline Poaceae & Arundo donax $\mathrm{L}$. & Sra-gu & Bamboo & $\begin{array}{l}\text { Leaves } \\
\text { and stems }\end{array}$ & Fuel & & & WangYH0097 \\
\hline Poaceae & $\begin{array}{l}\text { Bambusa teres } \\
\text { Munro }\end{array}$ & Li-shing & Bamboo & Culms & Making bow and arrow & 0.09 & 0.09 & WangYH0092 \\
\hline Poaceae & Coix lacryma-jobi L. & $\begin{array}{l}\text { Phon-pa- } \\
\text { lin }\end{array}$ & Herb & Seeds & $\begin{array}{l}\text { Boiled liquid for treating high blood } \\
\text { pressure. Ornament plant }\end{array}$ & 0.27 & 0.27 & WangYH0179 \\
\hline Poaceae & $\begin{array}{l}\text { Dendrocalamus } \\
\text { tibeticus Hsueh \& T. } \\
\text { P. Yi }\end{array}$ & Ha-po & Bamboo & $\begin{array}{l}\text { Culms and } \\
\text { shoots. }\end{array}$ & $\begin{array}{l}\text { Food (a kind of vegetable). Making } \\
\text { agriculture tools }\end{array}$ & 0.1 & 0.1 & WangYH0160 \\
\hline Poaceae & $\begin{array}{l}\text { Eleusine coracana } \\
\text { (L.) Gaertn. }\end{array}$ & Kon-pu & Herb & Seeds & Making alcohol beverages. Extracting starch & 0.47 & 0.5 & WangYH0001 \\
\hline Poaceae & $\begin{array}{l}\text { Imperata cylindrica } \\
\text { (L.) Raeusch. }\end{array}$ & Shing-pu & Herb & Leaves & Thatching & 0.06 & 0.06 & $18 \mathrm{CS} 16843$ \\
\hline Poaceae & $\begin{array}{l}\text { Phyllostachys } \\
\text { mannii Gamble }\end{array}$ & Suo-nong & Bamboo & Burgeons & Food (a kind of vegetable) & 0.08 & 0.08 & 18CS16907 \\
\hline Poaceae & $\begin{array}{l}\text { Sorghum bicolor (L.) } \\
\text { Moench }\end{array}$ & Phin-nang & Herb & $\begin{array}{l}\text { Stems and } \\
\text { seeds }\end{array}$ & $\begin{array}{l}\text { Stems are eaten directly. Seeds are used for } \\
\text { preparing alcohol beverages }\end{array}$ & 0.05 & 0.12 & $18 \mathrm{CS} 16814$ \\
\hline Poaceae & $\begin{array}{l}\text { Themeda villosa } \\
\text { (Lam.) A.Camus }\end{array}$ & Pi-li & Herb & Leaves & Thatching & 0.11 & 0.11 & $18 \mathrm{CS} 16842$ \\
\hline
\end{tabular}


Table 4 Ethnobotanical inventory of Monpa in Mêdog County, Tibet, China (Continued)

\begin{tabular}{|c|c|c|c|c|c|c|c|c|}
\hline Family name & Scientific name & $\begin{array}{l}\text { Vernacular } \\
\text { name }\end{array}$ & Habit & Parts used & Local use & $f$ & $\mathrm{Cl}$ & $\begin{array}{l}\text { Voucher } \\
\text { specimen } \\
\text { number }\end{array}$ \\
\hline Polygonaceae & $\begin{array}{l}\text { Fagopyrum } \\
\text { acutatum (Lehm.) } \\
\text { Mansf. ex } \\
\text { K.Hammer }\end{array}$ & $\begin{array}{l}\text { Pin-dae- } \\
\text { mu }\end{array}$ & Herb & Leaves & Food (a kind of vegetable). Forage & 0.13 & 0.15 & $18 \mathrm{CS} 16813$ \\
\hline Polygonaceae & $\begin{array}{l}\text { Fagopyrum } \\
\text { esculentum Moench }\end{array}$ & Ka-la & Herb & Fruits & Food (extracting starch) & 0.13 & 0.13 & $18 C S 16855$ \\
\hline Polygonaceae & $\begin{array}{l}\text { Fagopyrum } \\
\text { tataricum (L.) } \\
\text { Gaertn. }\end{array}$ & Ka-la & Herb & Seeds & Making alcohol beverages. Extracting starch & 0.17 & 0.21 & WangYH0182 \\
\hline Polygonaceae & $\begin{array}{l}\text { Persicaria capitata } \\
\text { (Buch.-Ham. ex } \\
\text { D.Don) H.Gross }\end{array}$ & $\begin{array}{l}\text { Long-pa- } \\
\text { dang- } \\
\text { mon-nang }\end{array}$ & Herb & $\begin{array}{l}\text { Whole } \\
\text { plant }\end{array}$ & Medicine used for burns & 0.05 & 0.05 & WangYH0155 \\
\hline Polygonaceae & $\begin{array}{l}\text { Persicaria nepalensis } \\
\text { (Meisn.) Miyabe }\end{array}$ & $\begin{array}{l}\text { Gong- } \\
\text { sgrer-ming }\end{array}$ & Herb & $\begin{array}{l}\text { Whole } \\
\text { plant }\end{array}$ & Food (a kind of fruit). Forage & 0.06 & 0.08 & $18 C S 16919$ \\
\hline Polygonaceae & $\begin{array}{l}\text { Polygonum } \\
\text { chinense var. } \\
\text { ovalifolium Meisner }\end{array}$ & $\begin{array}{l}\text { Gu-ju-ma- } \\
\text { shing }\end{array}$ & Herb & $\begin{array}{l}\text { Tender } \\
\text { stems and } \\
\text { leaves }\end{array}$ & Food (a kind of vegetable) & 0.09 & 0.09 & $18 \mathrm{CS} 16820$ \\
\hline Polyporaceae & Polyporus sp. & $\begin{array}{l}\text { Shing-pa- } \\
\mathrm{mu}\end{array}$ & Fungi & Mushroom & Food (a kind of vegetable) & 0.09 & 0.09 & $18 \mathrm{CS} 16917$ \\
\hline Primulaceae & $\begin{array}{l}\text { Embelia floribunda } \\
\text { Wall. }\end{array}$ & Ju-bu-ru & Vine & $\begin{array}{l}\text { Fruits and } \\
\text { roots }\end{array}$ & Food (a kind of fruit) & 0.09 & 0.09 & $18 \mathrm{CS} 16927$ \\
\hline Primulaceae & $\begin{array}{l}\text { Maesa marioniae } \\
\text { Merr. }\end{array}$ & Ker-seh-ru & Shrub & Fruits & Food (a kind of fruit) & & & $18 C S 16953$ \\
\hline Primulaceae & $\begin{array}{l}\text { Maesa rugosa C. B. } \\
\text { Clarke }\end{array}$ & $\begin{array}{l}\text { Lho-ku- } \\
\text { mer-shing }\end{array}$ & Shrub & Leaves & Making agriculture tools & 0.09 & 0.09 & $18 \mathrm{CS} 16957$ \\
\hline Ranunculaceae & $\begin{array}{l}\text { Clematis } \\
\text { napaulensis DC. }\end{array}$ & & Vine & Leaves & Forage & & & WangYH0058 \\
\hline Rhamnaceae & $\begin{array}{l}\text { Hovenia acerba } \\
\text { Lindl. }\end{array}$ & Shi-pi & Tree & Fruits & Boiled or eaten directly, used for alcoholism & & & $18 \mathrm{CS} 16884$ \\
\hline Rhamnaceae & $\begin{array}{l}\text { Rhamnus napalensis } \\
\text { (Wall.) M. A. } \\
\text { Lawson }\end{array}$ & $\begin{array}{l}\text { Da-gor- } \\
\text { shing }\end{array}$ & Shrub & Fruits & Food (a kind of fruit) & 0.06 & 0.06 & $18 \mathrm{CS} 16923$ \\
\hline Rosaceae & $\begin{array}{l}\text { Chaenomeles } \\
\text { cathayensis (Hemsl.) } \\
\text { C. K. Schneid. }\end{array}$ & $\begin{array}{l}\text { Tong-ju- } \\
\text { bha-bu }\end{array}$ & Tree & Fruits & Food (a kind of fruit) & 0.27 & 0.27 & 18CS16921 \\
\hline Rosaceae & $\begin{array}{l}\text { Duchesnea indica } \\
\text { (Jacks.) Focke }\end{array}$ & $\begin{array}{l}\text { Pu-tshu-la- } \\
\text { gong }\end{array}$ & Herb & Fruits & $\begin{array}{l}\text { Food (a kind of fruit), boiled the dried fruits } \\
\text { used for detoxification and treating bruises }\end{array}$ & 0.41 & 0.41 & $18 \mathrm{CS} 16875$ \\
\hline Rosaceae & $\begin{array}{l}\text { Laurocerasus } \\
\text { undulata (Buch.- } \\
\text { Ham. ex D. Don) M. } \\
\text { Roemer }\end{array}$ & Dan-bur & $\begin{array}{l}\text { Tree or } \\
\text { shrub }\end{array}$ & Seeds & Extracting oil. Religious ritual use & & & WangYH0068 \\
\hline Rosaceae & $\begin{array}{l}\text { Prunus persica (L.) } \\
\text { Batsch }\end{array}$ & Lin-shing & Tree & Fruits & Food (a kind of fruit) & 0.33 & 0.33 & $18 C S 16956$ \\
\hline Rosaceae & Rubus ellipticus Sm. & Tser-gong & Shrub & Fruits & Food (a kind of fruit) & 0.33 & 0.33 & $18 \mathrm{CS} 16850$ \\
\hline Rosaceae & $\begin{array}{l}\text { Rubus niveus } \\
\text { Thunb. }\end{array}$ & $\begin{array}{l}\text { Tu-lu-tse- } \\
\text { gong }\end{array}$ & Shrub & Fruits & Food (a kind of fruit) & 0.05 & 0.05 & $18 \mathrm{CS} 16815$ \\
\hline Rosaceae & $\begin{array}{l}\text { Rubus sumatranus } \\
\text { Miq. }\end{array}$ & $\begin{array}{l}\text { Ga-bu- } \\
\text { dong-tse- } \\
\text { gong }\end{array}$ & Shrub & Fruits & Food (a kind of fruit) & 0.14 & 0.14 & 18CS16939 \\
\hline Rubiaceae & $\begin{array}{l}\text { Luculia gratissima } \\
\text { (Wall.) Sweet }\end{array}$ & $\begin{array}{l}\text { Nom- } \\
\text { meng }\end{array}$ & $\begin{array}{l}\text { Tree or } \\
\text { shrub }\end{array}$ & Flowers & Religious ritual use & & & WangYH0051 \\
\hline Rubiaceae & $\begin{array}{l}\text { Mussaenda } \\
\text { pubescens Dryand. }\end{array}$ & $\begin{array}{l}\text { Meng-gya- } \\
\text { bai-dong- } \\
\text { shing }\end{array}$ & Shrub & Leaves & Seasonal indication & 0.06 & 0.06 & 18CS16941 \\
\hline
\end{tabular}


Table 4 Ethnobotanical inventory of Monpa in Mêdog County, Tibet, China (Continued)

\begin{tabular}{|c|c|c|c|c|c|c|c|c|}
\hline Family name & Scientific name & $\begin{array}{l}\text { Vernacular } \\
\text { name }\end{array}$ & Habit & Parts used & Local use & $f$ & $\mathrm{Cl}$ & $\begin{array}{l}\text { Voucher } \\
\text { specimen } \\
\text { number }\end{array}$ \\
\hline Rubiaceae & $\begin{array}{l}\text { Ophiorrhiza } \\
\text { medogensis H. Li }\end{array}$ & $\begin{array}{l}\text { Ming-zi- } \\
\text { ma-mu }\end{array}$ & Herb & $\begin{array}{l}\text { Whole } \\
\text { plant }\end{array}$ & Food (a kind of vegetable) & 0.11 & 0.11 & $18 \mathrm{CS} 16862$ \\
\hline Rubiaceae & $\begin{array}{l}\text { Rubia } \\
\text { membranacea Diels }\end{array}$ & Lae-nyi & Herb & Stems & Dye plant & & & WangYH0114 \\
\hline Rubiaceae & $\begin{array}{l}\text { Rubia wallichiana } \\
\text { Decne. }\end{array}$ & Lae-nyi & Herb & Stems & Dye plant & 0.3 & 0.3 & WangYH0127 \\
\hline Rubiaceae & Spiradiclis sp. & Mi-zu-ma & Herb & $\begin{array}{l}\text { Whole } \\
\text { plant }\end{array}$ & Food (a kind of vegetable) & 0.09 & 0.09 & $18 \mathrm{CS} 16833$ \\
\hline Rubiaceae & $\begin{array}{l}\text { Uncaria } \\
\text { rhynchophylla (Miq.) } \\
\text { Miq. ex Havil. }\end{array}$ & Gou-du & Liana & Stems & $\begin{array}{l}\text { Boiled liquid for treating high blood } \\
\text { pressure }\end{array}$ & & & 18CS16962 \\
\hline Rubiaceae & $\begin{array}{l}\text { Uncaria scandens } \\
\text { (Sm.) Hutch. }\end{array}$ & Tsae-tsu & Liana & Leaves & Boiled liquid for treating epilepsy & & & $18 \mathrm{CS} 16905$ \\
\hline Rubiaceae & $\begin{array}{l}\text { Wendlandia } \\
\text { tinctoria (Roxb.) DC. }\end{array}$ & $\begin{array}{l}\text { Mehi- } \\
\text { neng- } \\
\text { nang-shi }\end{array}$ & $\begin{array}{l}\text { Tree or } \\
\text { shrub }\end{array}$ & Stems & Making agriculture tools & 0.17 & 0.17 & $18 \mathrm{CS} 16900$ \\
\hline Rutaceae & Citrus medica L. & $\begin{array}{l}\text { Hpo-rang- } \\
\text { nying-pa }\end{array}$ & $\begin{array}{l}\text { Tree or } \\
\text { shrub }\end{array}$ & Fruits & Medicine used for treating cold & & & \\
\hline Rutaceae & $\begin{array}{l}\text { Toddalia asiatica } \\
\text { (L.) Lam. }\end{array}$ & $\begin{array}{l}\text { Ae-pi-ka- } \\
\text { ba }\end{array}$ & Shrub & Seeds & $\begin{array}{l}\text { Seed oil with butter is used for treating } \\
\text { epilepsy }\end{array}$ & & & $18 \mathrm{CS} 16961$ \\
\hline Rutaceae & $\begin{array}{l}\text { Zanthoxylum } \\
\text { motuoense C. C. } \\
\text { Huang }\end{array}$ & Gei & Tree & Fruits & $\begin{array}{l}\text { Crushed fruits are used for treating bad skin } \\
\text { odour. Spice plant }\end{array}$ & 0.56 & 0.56 & $18 \mathrm{CS} 16895$ \\
\hline Sabiaceae & $\begin{array}{l}\text { Meliosma pinnata } \\
\text { (Roxb.) Maxim. }\end{array}$ & $\begin{array}{l}\text { Beng-shar- } \\
\text { shing }\end{array}$ & Tree & Flowers & Seasonal indication & 0.06 & 0.06 & 18CS16945 \\
\hline Scrophulariaceae & $\begin{array}{l}\text { Buddleja asiatica } \\
\text { Lour. }\end{array}$ & Yang-ren & Shrub & $\begin{array}{l}\text { Whole } \\
\text { plant }\end{array}$ & Making alcohol beverages & & & $18 \mathrm{CS} 16914$ \\
\hline Solanaceae & $\begin{array}{l}\text { Datura stramonium } \\
\text { L. }\end{array}$ & $\begin{array}{l}\text { Yun-ma- } \\
\text { chu-dong }\end{array}$ & $\begin{array}{l}\text { Herb or } \\
\text { subshrub }\end{array}$ & Seeds & Medicine used for treating toothache & 0.06 & 0.06 & $18 \mathrm{CS} 16837$ \\
\hline Solanaceae & $\begin{array}{l}\text { Nicotiana tabacum } \\
\text { L. }\end{array}$ & Da-mu-ga & Herb & Leaves & Crushed leaves used for treating sinusitis & & & $18 \mathrm{CS} 16906$ \\
\hline Solanaceae & $\begin{array}{l}\text { Solanum } \\
\text { americanum Mill. }\end{array}$ & Gu-ju-shu & Herb & Burgeons & Food (a kind of vegetable) & 0.14 & 0.14 & $18 \mathrm{CS} 16838$ \\
\hline Solanaceae & $\begin{array}{l}\text { Solanum } \\
\text { aculeatissimum } \\
\text { Jacq. }\end{array}$ & $\begin{array}{l}\text { Kha-lang- } \\
\text { gyi }\end{array}$ & $\begin{array}{l}\text { Herb to } \\
\text { subshrub }\end{array}$ & Roots & $\begin{array}{l}\text { Crushed roots and the leaves of Luffa } \\
\text { cylindrica are used for treating psoriasis }\end{array}$ & & & $18 \mathrm{CS} 16866$ \\
\hline Solanaceae & $\begin{array}{l}\text { Solanum torvum } \\
\text { Sw. }\end{array}$ & $\begin{array}{l}\text { Kha-lang- } \\
\text { gyi }\end{array}$ & Shrub & Fruits & Food (a kind of vegetable) & 0.2 & 0.2 & $18 \mathrm{CS} 16812$ \\
\hline Taxaceae & $\begin{array}{l}\text { Torreya grandis var. } \\
\text { yunnanensis } \\
\text { (W.C.Cheng \& } \\
\text { L.K.Fu) Silba }\end{array}$ & $\begin{array}{l}\text { Gae-long- } \\
\text { shing }\end{array}$ & Tree & Fruits & Food (a kind of fruit) & & & $18 \mathrm{CS} 16880$ \\
\hline Thymelaeaceae & $\begin{array}{l}\text { Edgeworthia } \\
\text { gardneri (Wall.) } \\
\text { Meisn. }\end{array}$ & $\begin{array}{l}\text { Sho-gu- } \\
\text { shing/ Ju- } \\
\text { pu -shing }\end{array}$ & Tree & Barks & Papermaking & 0.05 & 0.05 & WangYH0006 \\
\hline Urticaceae & $\begin{array}{l}\text { Debregeasia } \\
\text { longifolia (Burm.f.) } \\
\text { Wedd. }\end{array}$ & $\begin{array}{l}\text { Rang- } \\
\text { shing }\end{array}$ & Shrub & Roots & $\begin{array}{l}\text { Boiled liquid for preventing miscarriage and } \\
\text { treating bruises }\end{array}$ & & & $18 \mathrm{CS} 16870$ \\
\hline Urticaceae & $\begin{array}{l}\text { Elatostema } \\
\text { cuneiforme } \\
\text { W.T.Wang }\end{array}$ & $\begin{array}{l}\text { Tsen-tsen- } \\
\text { pa }\end{array}$ & Herb & $\begin{array}{l}\text { Aerial } \\
\text { parts }\end{array}$ & Forage & 0.08 & 0.08 & WangYH0091 \\
\hline Urticaceae & $\begin{array}{l}\text { Elatostema } \\
\text { nasutum Hook.f. }\end{array}$ & Da-mi-ru & Herb & Leaves & $\begin{array}{l}\text { Food (a kind of vegetable boiled in the } \\
\text { water first) }\end{array}$ & & & $18 \mathrm{CS} 16848$ \\
\hline Urticaceae & Gonostegia hirta & Ro-gyi-ba & Herb & Whole & Food (a kind of vegetable) & 0.08 & 0.08 & $18 \mathrm{CS} 16924$ \\
\hline
\end{tabular}


Table 4 Ethnobotanical inventory of Monpa in Mêdog County, Tibet, China (Continued)

\begin{tabular}{|c|c|c|c|c|c|c|c|c|}
\hline Family name & Scientific name & $\begin{array}{l}\text { Vernacular } \\
\text { name }\end{array}$ & Habit & Parts used & Local use & $f$ & $\mathrm{Cl}$ & $\begin{array}{l}\text { Voucher } \\
\text { specimen } \\
\text { number }\end{array}$ \\
\hline & $\begin{array}{l}\text { (Blume ex Hassk.) } \\
\text { Miq. }\end{array}$ & & & plant & & & & \\
\hline Urticaceae & $\begin{array}{l}\text { Pilea hilliana Hand.- } \\
\text { Mazz. }\end{array}$ & $\begin{array}{l}\text { Ru-gong- } \\
\text { su-gang }\end{array}$ & Herb & Leaves & Food (a kind of vegetable) & 0.05 & 0.05 & WangYH0159 \\
\hline Urticaceae & $\begin{array}{l}\text { Poikilospermum } \\
\text { lanceolatum } \\
\text { (Trécul) Merr. }\end{array}$ & Ba-mi-ru & Shrub & $\begin{array}{l}\text { Leaves } \\
\text { and aerial } \\
\text { roots }\end{array}$ & $\begin{array}{l}\text { Leaves are used for forage. Aerial roots are } \\
\text { used for rope }\end{array}$ & 0.34 & 0.36 & $18 \mathrm{CS} 16830$ \\
\hline Urticaceae & Urtica mairei H. Lév. & $\begin{array}{l}\text { Gang- } \\
\text { dang-gyal- } \\
\text { zu }\end{array}$ & Herb & Leaves & Food (a kind of vegetable) & & & WangYH0040 \\
\hline Violaceae & Viola sp. & Pian-mier & Herb & $\begin{array}{l}\text { Whole } \\
\text { plant }\end{array}$ & $\begin{array}{l}\text { Boiled liquid for clearing heat and } \\
\text { detoxification }\end{array}$ & & & WangYH0066 \\
\hline Vitaceae & $\begin{array}{l}\text { Tetrastigma } \\
\text { serrulatum (Roxb.) } \\
\text { Planch. }\end{array}$ & Ju-bae-ru & Liana & Fruits & Food (a kind of fruit) & 0.28 & 0.28 & $18 \mathrm{CS} 16828$ \\
\hline Xanthorrhoeaceae & $\begin{array}{l}\text { Hemerocallis fulva } \\
\text { (L.) L. }\end{array}$ & Chu-ta & Herb & $\begin{array}{l}\text { Leaves } \\
\text { and } \\
\text { flowers }\end{array}$ & Food (a kind of vegetable) & 0.17 & 0.17 & $18 \mathrm{CS} 16887$ \\
\hline Zingiberaceae & $\begin{array}{l}\text { Alpinia bambusifolia } \\
\text { C. F. Liang \& D. } \\
\text { Fang }\end{array}$ & Tar-gang & Herb & $\begin{array}{l}\text { Flower } \\
\text { buds }\end{array}$ & Food (sweet taste) & 0.2 & 0.2 & WangYH0101 \\
\hline Zingiberaceae & $\begin{array}{l}\text { Alpinia malaccensis } \\
\text { (Burm.f.) Roscoe }\end{array}$ & Tar-gang & Herb & $\begin{array}{l}\text { Flower } \\
\text { buds }\end{array}$ & Food (sweet taste) & 0.2 & 0.2 & WangYH0103 \\
\hline Zingiberaceae & $\begin{array}{l}\text { Curcuma aromatica } \\
\text { Salisb. }\end{array}$ & Dgrong & Herb & $\begin{array}{l}\text { Roots and } \\
\text { leaves }\end{array}$ & $\begin{array}{l}\text { Boiled roots used for treating heat stroke, } \\
\text { irregular menstruation and boiled leaves } \\
\text { used for treating alcoholism }\end{array}$ & & & $18 \mathrm{CS} 16879$ \\
\hline Zingiberaceae & Curcuma longa $L$. & Dgrong & Herb & Roots & Dye plant & 0.22 & 0.22 & WangYH0070 \\
\hline Zingiberaceae & $\begin{array}{l}\text { Hedychium } \\
\text { coccineum Buch.- } \\
\text { Ham. ex Sm. }\end{array}$ & $\begin{array}{l}\text { Ma-mi-niu- } \\
\text { mu }\end{array}$ & Herb & Burgeons & Food (a kind of vegetable) & 0.05 & 0.05 & $18 C S 16849$ \\
\hline Zingiberaceae & $\begin{array}{l}\text { Hornstedtia tibetica } \\
\text { T.L.Wu \& S.J.Chen }\end{array}$ & Su-mi & Herb & Fruits & Food (a kind of fruit) & 0.08 & 0.08 & $18 \mathrm{CS} 16847$ \\
\hline
\end{tabular}

Voucher specimen number with CS means collection section

\section{Supplementary information}

Supplementary information accompanies this paper at https://doi.org/10. 1186/s13002-020-0355-7.

Additional file 1. The Tibetan alphabet (Consonants).

Additional file 2. The Tibetan alphabet (Vowels).

\section{Acknowledgments}

We are very thankful to the local people in Beibeng Village, Jiangxin Village, Xirang Village, Gelin Village, De'ergong Village, Badeng Village, Acang Village, Dexing Village, Hezha Village, Naerdong Village, Bangxin Village, and Gengbang Village in Mêdog County, who have provided valuable information related to the useful plant resources. Extremely gratitude is expressed to the families of Rinchin Ihamo for their kind hospitality, and to Padma Dorje for his genuine assistance.

\section{Authors' contributions}

SL and YHW conceived and designed the research. SL, YZ, YJG, LXY, and YHW collected the data. YZ and YJG provided the botanical identification. SL analyzed the data and prepared the manuscript. LXY and SL took the photographs. YHW reviewed the manuscript. All authors read and approved the final manuscript.

\section{Funding}

This work was supported by the Strategic Priority Research Program of Chinese Academy of Sciences (No. XDA20050204, XDA19050301, and XDA19050303) and the 13th Five-year Informatization Plan of Chinese Academy of Sciences (No.XXH13506), and the National Public Scientific Data Center for Basic Sciences.

Availability of data and materials

All data generated or analysed during this study are included in this published article and its supplementary information files.

\section{Ethics approval and consent to participate}

The authors asked for permission from the local authorities and the people interviewed to carry out the study.

\section{Consent for publication}

The people interviewed were informed about the study's objectives and the eventual publication of the information gathered, and they were assured that the informants' identities would remain undisclosed.

\section{Competing interests}

The authors declare that they have no competing interests. 


\section{Author details}

'Department of Economic Plants and Biotechnology, Key Laboratory of Economic Plants and Biotechnology, Kunming Institute of Botany, Chinese Academy of Sciences, Kunming 650201, China. ${ }^{2}$ Key Laboratory for Microbial Resources of the Ministry of Education, Yunnan Institute of Microbiology, School of Life Sciences, Yunnan University, Kunming 650091, China. ${ }^{3}$ Germplasm Bank of Wild Species of China, Kunming Institute of Botany, Chinese Academy of Sciences, Kunming 650201, Yunnan, China. ${ }^{4}$ University of Chinese Academy of Sciences, Beijing CN-100049, China.

Received: 11 September 2019 Accepted: 13 January 2020 Published online: 30 January 2020

\section{References}

1. Salick J, Amend A, Anderson D, Hoffmeister K, Gunn B, Zhendong F. Tibetan sacred sites conserve old growth trees and cover in the eastern Himalayas. Biodivers Conserv. 2007;16(3):693-706. https://doi.org/10.1007/s10531-005-4381-5.

2. Veer V, Gopalakrishnan R. Herbal insecticides, repellents and biomedicines: effectiveness and commercialization. New Delhi: Springer; 2016. https://doi. org/10.1007/978-81-322-2704-5.

3. Liu YC, Dao ZL, Yang CY, Liu YT, Long CL. Medicinal plants used by Tibetans in Shangri-la, Yunnan, China. J Ethnobiol Ethnomed. 2009;5(1):15. https://doi org/10.1186/1746-4269-5-15.

4. Ju Y, Zhuo JX, Liu B, Long CL. Eating from the wild: diversity of wild edible plants used by Tibetans in Shangri-la region, Yunnan, China. J Ethnobiol Ethnomed. 2013;9(1):28. https://doi.org/10.1186/1746-4269-9-28.

5. Kang Y, Luczaj L, Kang J, Wang F, Hou JJ, Guo QP. Wild food plants used by the Tibetans of Gongba Valley (Zhouqu county, Gansu, China). J Ethnobiol Ethnomed. 2014;10(1):20. https://doi.org/10.1186/1746-4269-10-20.

6. Kang J, Kang YX, Ji XL, Guo QP, Jacques G, Pietras M, Luczaj N, Li DW, Luczaj L. Wild food plants and fungi used in the mycophilous Tibetan community of Zhagana (Tewo County, Gansu, China). J Ethnobiol Ethnomed. 2016;12(1): 21. https://doi.org/10.1186/s13002-016-0094-y.

7. Wang L. Investigation of Mêdog Village. Beijing: China Economic Publishing House; 2011.

8. Yang N, Zhou X. Plants of the Mêdog. Bejing: China Forestry Publishing House; 2015.

9. Ethnologue. Languages of the world, twenty-first edition. Dallas: SIL International; 2018. http://www.ethnologue.com. Accessed 15 Dec 2018

10. Zhang X. An overview of historial culture, literature and art of Monpa people. Popular Lit Art. 2018;12:40-1.

11. Chen L. On the literary and artistic exchange between the Tibetan and the Moinba People. Tibetan Art Stud. 1995;1:56-61.

12. $L$ Z, Hong M. Monpa ethnic group: investigation of Cuona County, Gongri Town in Xizang. Kunming: Yunnan University Publishing House; 2004

13. Li S. Research on traditional settlements space of the Moinba Nationality in Mêdog County. Beijing: Beijing University of Civil Engineering and Architecture; 2017

14. Anonymous. Moinba ethnic group and its customs. In: Anonymous, editors. Tibet travel guide-let's travel Tibet retrieved; 2013. p. 10-20.

15. Ladio AH, Lozada M. Nontimber forest product use in two human populations from northwest Patagonia: a quantitative approach. Hum Ecol. 2001;29(4):367-80. https://doi.org/10.1023/A:1013199103440.

16. Troter R, Logan M. Informant consensus: a new approach for identifying potentially effective medicinal plants. In: Etkin NL, editor. Indigenous medicine and diet: biobehavioural approaches. New York: Redgrave Bedford Hills; 1986. p. 91-112.

17. Tardío J, Pardo-de-Santayana M. Cultural importance indices: a comparative analysis based on the useful wild plants of southern Cantabria (Northern Spain). Econ Bot. 2008;62:24-39. https://doi.org/10.1007/s12231-007-9004-5.

18. Bhatia H, Sharma YP, Manhas RK, Kumar K. Traditionally used wild edible plants of district Udhampur, J\&K, India. J Ethnobiol Ethnomed. 2018;14(1):73. https://doi.org/10.1186/s13002-018-0272-1.

19. Tamang JP, Sarkar PK, Hesseltine CW. Traditional fermented foods and beverages of Darjeeling and Sikkim—a review. J Sci Food Agric. 1988;44(4): 375-85. https://doi.org/10.1002/jsfa.2740440410.

20. Uprety Y, Poudel RC, Shrestha KK, Rajbhandary S, Tiwari NN, Shrestha UB, Asselin $\mathrm{H}$. Diversity of use and local knowledge of wild edible plant resources in Nepal. J Ethnobiol Ethnomed. 2012;8(1):16. https://doi.org/10. 1186/1746-4269-8-16.
21. Li FF, Zhuo JX, Liu B, Jarvis D, Long CL. Ethnobotanical study on wild plants used by Lhoba people in Milin County, Tibet. J Ethnobiol Ethnomed. 2015; 11(1):23. https://doi.org/10.1186/s13002-015-0009-3.

22. Bhatia H, Sharma YP, Manhas RK, Kumar K. Ethnomedicinal plants used by the villagers of district Udhampur, J\&K, India. J Ethnopharmacol. 2014;151(2): 1005-18. https://doi.org/10.1016/j.jep.2013.12.017.

23. Huang A, Lü D. Study of the diet-value of Tibet Motuo stone casserole. J Fuzhou Univ (Nat Sci Edit). 2011;(4):613-6 CNKl:35-1117 /N.20110705.1518.015.

24. Kalita P, Sarma HN, Das AK. Evaluation of nutritional potential of five unexplored wild edible food plants from Eastern Himalayan biodiversity hotspot region (India). Waset Org. 2014;8(3):215-8.

25. Wangchuk P, Pyne SG, Keller PA. Ethnobotanical authentication and identification of Khrog-sman (lower elevation medicinal plants) of Bhutan. J Ethnopharmacol. 2011;134(3):813-23. https://doi.org/10.1016/j. jep.2011.01.034

26. Liu YJ, Ahmed S, Liu B, Guo ZY, Huang WJ, Wu XJ, Li SH, Zhou JJ, Lei QY, Long CL. Ethnobotany of dye plants in Dong communities of China. J Ethnobio Ethnomed. 2014;10(1):1-9. https://doi.org/10.1186/1746-4269-10-23.

27. Li S, Cunningham AB, Fan RY, Wang YH. Identity blues: the ethnobotany of the indigo dyeing by Landian Yao (lu Mien) in Yunnan, Southwest China. J Ethnobiol Ethnomed. 2019:15(1):13. https://doi.org/10.1186/s13002-019-0289-0.

28. Daiuto É, Cereda M, Sarmento S, Vilpoux O. Effects of extraction methods on yam (Dioscorea alata) starch characteristics. Starch-Stärke. 2005;57(3-4): 153-60. https://doi.org/10.1002/star.200400324.

29. Pachuau L, Dutta RS, Devi TB, Deka D, Hauzel L. Taro starch (Colocasia esculenta) and citric acid modified taro starch as tablet disintegrating agents. Int J Biol Macromol. 2018;118:397-405. https://doi.org/10.1016/j.ijbiomac.2018.06.086.

30. Ellen R. Distribution and variation in sago extraction equipment: convergent and secondary technologies in island southeast Asia. Archaeol Ocean. 2008; 43(2):62-74. https://doi.org/10.2307/40387408

31. Cunningham $A B$, Ingram $W$, Kadati $W D$, et al. Hidden economies, future options: trade in non-timber products from forests and agroforestry systems in eastern Indonesia. ACIAR Technical Report: Canberra; 2011

32. Geng YF, Zhang Y, Ranjitkar S, Huai HY, Wang YH. Traditional knowledge and its transmission of wild edibles used by the Naxi in Baidi Village, northwest Yunnan province. J Ethnobiol Ethnomed. 2016; 12(1):10. https://doi.org/10.1186/s13002-016-0082-2

33. Longvah $T$, Deosthale YG. Chemical and nutritional studies on hanshi (perilla frutescens), a traditional oilseed from northeast india. J Am Oil Chem Soc. 1991;68(10):781-4. https://doi.org/10.1007/BF02662172.

34. Ahmed HM, Tavaszi-Sarosi S. Identification and quantification of essential oil content and composition, total polyphenols and antioxidant capacity of Perilla frutescens (L.) Britt. Food Chem. 2019;275:730-8. https://doi.org/10. 1016/j.foodchem.2018.09.155.

35. Bhattarai S, Chaudhary RP, Cassandra LQ, Robin SLT. The use of medicinal plants in the trans-himalayan arid zone of Mustang district, Nepal. Ethnobiol Ethnomed. 2010;6:14. https://doi.org/10.1186/1746-4269-6-14.

36. Ayyanar M, Ignacimuthu S. Traditional knowledge of Kani tribals in Kouthalai of Tirunelveli hills, Tamil Nadu, India. J Ethnopharmacol. 2005:102:246-55. https://doi.org/10.1016/j.jep.2005.06.020

37. Subject database of china plant, medicinal plant database. Institute of Botany, Chinese Academy of Science, Beijing. 2014. http://www.plant.csdb. $\mathrm{cn} /$ herb. Accessed 8 Jun 2014.

38. Jiang B, Lu ZQ, Zhang HJ, Zhao QS, Sun HD. Diterpenoids from Isodon lophanthoides. Fitoterapia. 2000;71(4):360-4. https://doi.org/10.1016/S0367326X(00)00126-X.

39. Kanjilal PB, Kotoky $R$, Singh RS. Chemical composition of the leaf oil of Altingia excelsa Nornha. Flavour Frag J. 2003;18(5):449-50. https://doi.org/10.1002/ffj.1250.

40. Yang ZM, Li B, Liu PP, Chen YJ, Liu Y. Systematic preliminary research on the chemical components of Artemisia vestita wall. Med Plant. 2014; 3. https://doi.org/10.1071/MU902099i.

41. Deba F, Xuan TD, Yasuda M, Tawata S. Chemical composition and antioxidant, antibacterial and antifungal activities of the essential oils from Bidens pilosa Linn. var. Radiata. Food Control. 2008:19(4):346-52. https://doi. org/10.1016/j.foodcont.2007.04.011

42. Bansal SS, Muthuraman A, Gill NS, Bali M. Therapeutic potential of Citrus medica L. peel extract in carrageenan induced inflammatory pain in rat. J Pharmacol Toxicol. 2010:5(3):108. https://doi.org/10.3923/rimp.2009.123.133.

43. Yu F, Gao J, Zeng Y, Liu CX. Effects of adlay seed oil on blood lipids and antioxidant capacity in hyperlipidemic rats. J Sci Food Agric. 2011:91(10): 1843-8. https://doi.org/10.1002/jsfa.4393. 
44. Huang XZ, Wang YH, Yu SS, Fu GM, Hu YC. Iridoid glycosides and grayanane diterpenoids from the roots of Craibiodendron henryi. J Nat Prod. 2005;68(11):1646-50. https://doi.org/10.1021/np050261s.

45. Lee YL, Weng CC, Mau JL. Antioxidant properties of ethanolic and hot water extracts from the rhizome of Curcuma aromatica. J Food Biochem. 2010; 31(6):757-71. https://doi.org/10.1111/j.1745-4514.2007.00143.x

46. Gaire BP, Subedi L. A review on the pharmacological and toxicological aspects of Datura stramonium L. J Integr Med. 2013;11(2):73-9. https://doi. org/10.3736/jintegrmed2013016.

47. Liu R, Gu QQ, Cui CB, Han B, Cai B, Liu HB, Guan HS. Three phenolicsderived chemical constituents of Debregeasia longifolia (Burm. f.) Wedd. and their antitumor activity. Chin J Med Chem. 2004;14(4):193-6. https://doi.org/ 10.3969/j.issn.1005-0108.2004.04.001.

48. Bo Q, Han W, Da Z. Investigation on the chemical constituents of Debregeasia longifolia. Nat Prod Res Dev. 2003;15. https://doi.org/10.16333/j. 1001-6880.2003.01.007.

49. Lin Y. Effects of three cultivation environments on growth and functional components in Dendrobium catenatum C13. Zhejiang A and F University; 2017. doi:CNKI:CDMD:2.1017.254155

50. Koepfli JB, Mead JF, Brockman JA. Alkaloids of Dichroa febrifuga. I. isolation and degradative studies. J Am Chem Soc. 1949;71(3):1048. https://doi.org/ 10.1021/ja01171a080.

51. Xiang B, Yu X, Li B, Xiong Y, Long M, He Q. Characterization, antioxidant, and anticancer activities of a neutral polysaccharide from Duchesnea indica (Andr.) Focke. J Food Biochem. 2019;43(7). https://doi.org/10.1111/ffbc.12899.

52. Peng J, Lu Y, Chen D. Studies on the chemical constituents of Mockstrawberry (Duchesnea indica). Chin Tradit Herb Drugs. 1995;7. https://doi.org/10.7501/j.issn.0253-2670.1995.7.164.

53. Wang $\mathrm{HQ}$, Peng $\mathrm{CZ}$, Chen YG. Phenolics from Elaeocarpus braceanus. Chem Nat Compd. 2015;51(6):1167-8. https://doi.org/10.1007/s10600-015-1520-4.

54. Fu YC, Yan MM, Huang YL, Xu Y. Extraction technology optimization and antioxidant activity study of total flavones from Equisetum ramosissimum Desf. China J Tradit Chin Med Pharm. 2010;25(10):1580-3.

55. Xu FF, Fan CL, Wang L, Wang GC, Zhang XQ, Ye WC. Chemical constituents from the seeds of Hovenia acerba. J Jinan Univ. 2011;32(3):304-6. https://doi. org/10.1090/S0002-9939-2011-10775-5.

56. Ye HY, Chen $\perp$, Li YF, Peng AH, Fu A, Song H, Tang MH, Luo HD, Luo YF, Xu $Y B$, et al. Preparative isolation and purification of three rotenoids and one isoflavone from the seeds of Millettia pachycarpa Benth by high-speed counter-current chromatography. J Chromatogr A. 2008;1178(1-2):101-7. https://doi.org/10.1016/j.chroma.2007.11.060.

57. Talukdar SN, Hossain MN. Phytochemical, phytotherapeutical and pharmacological study of Momordica dioica. Evid Based Compl Alt Med. 2014;2:806082. https://doi.org/10.1155/2014/806082.

58. Tan YX, Liu C, Zhang T, Chen RY, Yu DQ. Bioactive constituents of Morus wittiorum. Phytochem Lett. 2010;3(2):57-61. https://doi.org/10.1016/.jphytol. 2009.11.006

59. Lee DH, Kim SH, Eun JS, Shin TY. Mosla dianthera inhibits mast cellmediated allergic reactions through the inhibition of histamine release and inflammatory cytokine production. Toxicol Appl Pharmacol. 2006;216(3):47984. https://doi.org/10.1016/j.taap.2006.06.007.

60. Tian Y, Ping D, Zhang Y. Overview on researches of medicinal use of tobacco. China Pharm. 2015;24(09):126-8.

61. Kathiriya A, Das K, Kumar EP, Mathai KB. Evaluation of antitumor and antioxidant activity of Oxalis corniculata Linn. against Ehrlich ascites carcinoma on mice. Iran J Cancer Prev. 2010;3(4):157-65 http://doi.org/2442.

62. Bureau of Chinese Herb Administration. Chinese Herbal Med. Shanghai: Shanghai Science and Technology Publishing Co; 1999.

63. Zhao HX, Bai H, Wei LI, Wang YS, Liu YJ. Chemical constituents from Polygonum capitatum. Nat Prod Res Develop. 2011;23(2):262-6. https://doi. org/10.1007/s10570-010-9464-0.

64. Zhang DD, Yang J, Luo JF, Li XN, Long CL, Wang YH. New aporphine alkaloids from the aerial parts of Piper semiimmersum. J Asian Nat Prod Res 2017;20(8):1. https://doi.org/10.1080/10286020.2017.1346630.

65. Paul A, Adnan M, Majumder M, Kar N, Meem M, Rahman MS, Rauniyar AK, Rahman N, Chy MNU, Kabir MSH. Anthelmintic activity of Piper sylvaticum Roxb. (family: Piperaceae): in vitro and in silico studies. Clin Phytosci. 2018; 4(1):17. https://doi.org/10.1186/s40816-018-0077-8.

66. Franke $\mathrm{H}$, Scholl R, Aigner A. Ricin and Ricinus communis in pharmacology and toxicology-from ancient use and "Papyrus Ebers" to modern perspectives and "poisonous plant of the year 2018". Naunyn
Schmiedeberg's Arch Pharmacol. 2019. https://doi.org/10.1007/s00210-01901691-6.

67. Dong $P$, Yan X, Kuang H, Han H. Experimental study of Sambucus williamsii Hance on anti-inflammatory and analgesia. Acta Chin Med Pharmacol. 2008; 36(5):18-20. https://doi.org/10.3969/j.issn.1002-2392.2008.05.007.

68. Bains JS, Singh J, Kamboj SS, Nijjar KK, Agrewala JN, Kumar V, Kumar A, Saxena AK. Mitogenic and anti-proliferative activity of a lectin from the tubers of Voodoo lily (Sauromatum venosum). Biochim Biophys Acta. 2005: 1723(1):163-74. https://doi.org/10.1016/j.bbagen.2005.02.006.

69. Krishnan VGM, Murugan K. Acute and subchronic toxicological evaluation of the purified protease inhibitor from the fruits of Solanum aculeatissimum Jacq. on Wistar rats. Cogent Biol. 2016;2(1):1191588. https://doi.org/10.1080/ 23312025.2016.1191588.

70. Nguelefack TB, Fodem C, Nguelefack MEP, Nyadjeu P, Wansi SL, Watcho P, Kamanyi A. Endothelium nitric oxide-independent vasorelaxant effects of the aqueous extract from Stephania abyssinica on the isolated rat thoracic aorta. J Complement Integr Med. 2014;12(1). https://doi.org/10.1515/jcim-2014-0022.

71. Ghosal S, Sharma PV, Jaiswal DK. Chemical constituents of gentianaceae XXIII: tetraoxygenated and pentaoxygenated xanthones and xanthone oglucosides of Swertia angustifolia Buch.-Ham. J Pharm Sci. 1978;67(1):55-60.

72. Shui-Xian LI, Chen XY. Pharmacognostic identification of Swertia nervosa (Wallich ex G.Don) C.B.Clarke. Med Plant. 2012;7.

73. Ping H, Gloria K, Wei SX, Waterman PG. Triterpene acids from Toddalia asiatica. Nat Prod Res Dev. 2005;17:404-8. https://doi.org/10.16333/j.10016880.2005.04.004.

74. Duraipandiyan $\mathrm{V}$, Ignacimuthu S. Antibacterial and antifungal activity of flindersine isolated from the traditional medicinal plant, Toddalia asiatica (L.) Lam. J Ethnopharmacol. 2009;123(3):494-8. https:/doi.org/10.1016/.j.jp.2009.02.020.

75. Ma B, Wu CF, Yang JY, Wang R, Kano Y, Yuan D. Three new alkaloids from the leaves of Uncaria rhynchophylla. Helv Chim Acta. 2010;92(8):1575-85. https://doi.org/10.1002/hlca.200900021.

76. Shi X. Studies on chemical composition and biological activity of Uncaria scandens. Lanzhou: Lanzhou University of Technology; 2012. https://doi.org/ 10.7666/d.D711760.

77. Zhu X, Dong X, Wang Y, Peng J, Luo S. Phenolic compounds from Viburnum cylindricum. Helv Chim Acta. 2005;88(2):339-42. https://doi.org/10. 1002/hlca.200590017.

78. Cardon D. Natural dyes sources, tradition, technology and science. London: Archetype Publications Ltd; 2007.

79. Vankar PS, Shanker R, Mahanta D, Tiwari SC. Ecofriendly sonicator dyeing of cotton with Rubia cordifolia Linn. using biomordant. Dyes Pigments. 2008; 76(1):207-12. https://doi.org/10.1016/j.dyepig.2006.08.023.

80. Jansen S, Broadley MR, Robbrecht E, Smets E. Aluminum hyperaccumulation in angiosperms: a review of its phylogenetic significance. Bot Rev. 2002;68(2):235-69. https:/doi.org/10.1663/0006-8101(2002)068[0235:AHIAAR]2.0.CO;2.

81. Cunningham AB, Maduarta IM, Howe J, Ingram W, Jansen S. Hanging by a thread: natural metallic mordant processes in traditional Indonesian textiles 1. Econ Bot. 2011:65(3):241-59. https://doi.org/10.1007/s12231-011-9161-4.

82. Wang S, Xie Y. China species red list. Beijing: Higher Education Press; 2004.

83. Yu N. God's inspiration for human culture: on the religious dancing of the Monpa. J Tibet Natl Inst. 1989;1:1-7.

84. Heizer RF. Aboriginal fish poisons. Anthropol Pap. 1953;38:225-83.

85. Béarez P. FOCUS: first archaeological indication of fishing by poison in a sea environment by the engoroy population at Salango (Manabí, Ecuador). J Archaeol Sci. 1998;25(10):943-8. https://doi.org/10.1006/jasc.1998.0330.

86. Wu Z, Raven P, Hong D. Flora of China. Beijing: Science Press, Missouri Botanical Garden Press; 1994

87. Bao L. The directly entering socialism ethnic groups and targeted poverty alleviation in Medog of Tibet. J Minzu Univ China (Philos Soc Sci Edit). 2018; 45(06):48-54. https://doi.org/10.15970/j.cnki.1005-8575.2018.06.005.

88. Benítez G, March-Salas M, Villa-Kamel A, Chaves-Jimenez U, Hernandez J, Montes-Osuna N, Moreno-Chocano J, Carinanos P. The genus Datura L. (Solanaceae) in Mexico and Spain-ethnobotanical perspective at the interface of medical and illicit uses. J Ethnopharmacol. 2018;219:133-51. https://doi.org/10.1016/j.jep.2018.03.007.

89. Diqing Tibetan Autonomous Prefecture Ethnic Affairs Commission. Diqing Tibetan medicine. Kunming: Yunnan Nationalities Publishing House; 1989.

\section{Publisher's Note}

Springer Nature remains neutral with regard to jurisdictional claims in published maps and institutional affiliations. 